\title{
Effectiveness of forestry best management practices in the United States: literature review
}

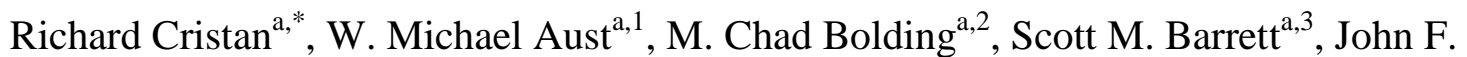 \\ Munsell $^{\mathrm{b}, 4}$, Erik Schilling ${ }^{\mathrm{c}, 5}$
}

${ }^{\mathrm{a}}$ Department of Forest Resources \& Environmental Conservation (FREC), Virginia Tech, 228 Cheatham Hall, 310 West Campus Drive, VA 24061, USA

${ }^{\mathrm{b}}$ FREC, Virginia Tech, 304 Cheatham Hall, 310 West Campus Drive, Blacksburg, VA 24061, USA

${ }^{\mathrm{c}}$ National Council for Air and Stream Improvement, Inc., 8270 McNatt Road, Aubrey, TX 76227

*Corresponding author. Tel.: (570) 490 4909. Email address: $\underline{\text { rcristan@ @t.edu }}$

${ }^{1}$ Tel.: (540) 231 4523. Email address: waust@vt.edu

${ }^{2}$ Tel.: (540) 231 6924. Email address: bolding@vt.edu

${ }^{3}$ Tel.: (540) 231 6702. Email address: sbarrett@vt.edu

${ }^{4}$ Tel.: (540) 231 1611. Email address: jfmunsel@vt.edu

${ }^{5}$ Tel.: (352) 244 1069. Email address: eschilling@ncasi.org 


\section{Abstract}

2

In response to the Federal Water Pollution Control Act (a.k.a., Clean Water Act) of 1972,

4 forestry best management practices (BMPs) were developed and subsequently implemented to

5 address NPS pollution during forest management. BMP guidelines vary by state and can be non-

6 regulatory, quasi-regulatory, or regulatory. To determine how effective the guidelines for

7 protecting water quality are, research literature relating to BMP effectiveness was evaluated.

8 Forestry BMP effectiveness studies are often site or region specific. Therefore, BMP research in

9 the United States was divided into three regions: northern, southern, and western. Thirty research

10 studies were reviewed for the southern region with the majority being conducted in the Piedmont

11 and Coastal Plain physiographic regions. The Western region had thirty-one studies, most of

12 which were in the Pacific Border physiographic region. The northern region had twenty studies

13 primarily in the northeastern states. Forestry BMP effectiveness research generally focused on

14 forest water quality from timber harvesting, site preparation, forest road construction and

15 maintenance, stream crossings, and other categories of forest operations. The literature indicates

16 that forestry BMPs protect water quality when constructed correctly and in adequate numbers.

17 Forestry BMP effectiveness studies allow state forestry BMP programs to evaluate progress in

18 reducing non-point source pollution and achieving water quality goals established under the

19 Clean Water Act (CWA). Furthermore, states have used research findings to change BMPs and

20 improve their guidelines. Although forestry BMPs have been proven to protect water quality,

21 they are still being refined to enhance their performance.

\section{Keywords}

Forestry best management practices (BMPs), BMP effectiveness studies, water quality, sediment delivery, erosion, forest operations 


\section{Acknowledgements}

Funding for this research was provided by the National Association of State Foresters, the

31 Sustainable Forestry Initiative, Virginia Agricultural Experiment Station, the Department of

32 Forest Resources and Environmental Conservation of Virginia Tech, and the MacIntire-Stennis

33 Program of the National Institute of Food and Agriculture, U.S. Department of Agriculture.

\section{Introduction}

Following passage of the Federal Water Pollution Control Act of 1972 (Clean Water Act or

38 CWA), states developed and implemented forestry best management practices (BMPs) to reduce

39 nonpoint source pollution (NPSP) during forest management (Phillips and Blinn, 2004). The

40 CWA includes requirements for both point source pollution (PSP) and NPSP and defines PSP to

41 include identifiable pollution discharge areas that are traceable to an outlet. Conversely, NPSP is

42 pollution where discharge areas are not readily identifiable and typically include agricultural and

43 forestry operations because a pollutant cannot be attributed to a specific site or operation and is

44 usually induced by natural erosive processes, such as surface runoff from rainfall or snowmelt

45 (US EPA, 2005). The CWA (section 208) defines timber harvesting and silvicultural operations

46 as NPSP (Grace, 2005). The U.S. Environmental Protection Agency (EPA) required states to

47 adopt NPSP control programs for forestry activities and suggest states follow either a regulatory

48 or non-regulatory approach to meet NPSP recommendations and goals for water quality (Ice et

49 al., 2004). In 1987, congress amended the CWA (Water Quality Act) to include Section 319 to

50 assist states with the development and funding of state NPSP control programs (US EPA, 2005).

51 In essence, Section 319 allows EPA to grant state forestry agencies financial assistance for

52 implementing management programs to reduce NPSP. 
53 Although forestry BMPs differ by state, prescriptions are typically similar in that they include

54 some variation of the following forestry operational categories: forest road construction and

55 maintenance, log landings (decks), skid trails, stream side management zones (SMZs), stream

56 crossings, wetland protection and management, timber harvesting, site preparation, and

57 reforestation. Some states have also developed additional BMPs for wildlife protection (FDACS,

58 2014) or woody biomass harvesting (Fritts et al., 2014).

59 Northeastern and Pacific Northwest (includes California) states typically follow a Forest Practice

60 Act (FPA) that requires use of specific BMPs during forest management. In contrast southeastern

61 states generally use a voluntary approach whereby the logger or landowner can select from a

62 suite of BMP recommendations and decide which prescription best meets water quality

63 protection needs. Finally, some states have quasi-regulatory BMP programs where prescriptions

64 may be voluntary but landowners have certain legal requirements such as notifying a state

65 agency of intent to harvest or applying for permits to install stream crossings. Regardless of the

66 approach, all states have regulatory authority to stop or regulate 'bad actors' if they fail to follow

67 recommended BMPs and damage water resources (NCASI, 1994; NCASI, 1996). State forestry

68 agencies most commonly lead BMP implementation and compliance reports. Forestry BMP

69 strategies, techniques, and monitoring vary significantly by state and region. States also differ

70 regarding how they select and monitor sites to document BMP implementation and compliance.

71 Appropriately implemented BMPs have positive influences on stream health, including stream

72 temperature and nutrients (Arthur et al., 1998; Clinton, 2011; Edwards and Williard, 2010; Keim

73 and Schoenholtz, 1999; Wilkerson et al., 2006). However, sediment is typically considered to be

74 the most significant water pollutant associated with forest management (US EPA, 2005; Yoho,

75 1980). Forestry BMPs have been reported to improve water quality (80-90\%) when compared 
76 prior practices (Ice, 2004; NCASI, 2012; Loehle et al., 2014).BMP development has been an

77 ongoing process which began with defining potential water quality problems, formulating

78 solutions, adopting practical and cost-effective BMPs, and monitoring their implementation (Ice,

79 2004). Forestry BMP effectiveness studies evaluate whether BMP implementation fully achieves

80 the goal of protecting water quality. Forestry BMPs will continue to evolve over time as water

81 quality standards are redefined and performance measures are changed (Rummer, 2004). Federal

82 and state agencies and universities have completed or have ongoing implementation and

83 effectiveness studies (NCASI, 2012).

84 Literature reviews addressing the effectiveness of forestry BMPs have been previously

85 conducted. Aust and Blinn (2004) reviewed timber harvesting and site preparation BMP research

86 results in the eastern US. Ice et al. (2004) assessed the implementation and effectiveness of

87 BMPs in the western US. Shepard (2006) reviewed BMP use in the US with emphasis on

88 suitability for biomass harvesting operations. Croke and Hairsine (2006) reviewed sediment

89 delivery in managed forests. Anderson and Lockaby (2011) evaluated the effectiveness of BMPs

90 for sediment control in the southeastern US. These previous literature reviews focus on broader

91 categories of operations such as timber harvesting, site preparation, and biomass harvesting

92 while this review focuses on more specific operational categories (timber harvesting, skid trails,

93 forest roads, streamside management zones, site preparation, etc.) and seeks to comprehensively

94 evaluate BMP effectiveness studies for the three major wood producing regions of the US so that

95 forest managers and agency personnel have current documentation of BMP efficacy within their

96 operational area.

97 2. Forestry BMP Effectiveness Study Literature Review Methodology 
98 This review provides an overview of forestry BMP effectiveness and related studies by region of

99 the United States (US). Southern, Western, and Northern regions are based on the geographic

100 grouping of States as noted by the Southern Group of State Foresters (SGSF), Council of

101 Western State Foresters (CWSF), and the Northeastern Area Association of State Foresters

102 (NAASF). This review concentrated on BMP research that was published in peer-reviewed

103 literature, had a direct emphasis on how BMP implementation levels would affect soil erosion

104 and or stream sedimentation, and primarily focused on relatively recent literature (past 20 years)

105 so that the findings are more indicative of current forest operations, techniques, and equipment

106 and BMP prescriptions. To fill in gaps, a few studies dating farther back were included in the

107 review. However, we acknowledge that this limitation does not account for much of the early

108 BMP research established by US Forest Service researchers at sites such as Hubbard Brook,

109 Coweeta, Parsons, and the HJ Andrews watersheds. Our BMP efficacy definition is intentionally

110 more inclusive than Edwards and Williard (2010) who focused only on studies that compared in-

111 stream sediment levels to differing levels of BMP prescriptions. Finally, we include

112 comparisons of soil erosion with different levels of BMPs as we believe it is a reasonable

113 assumption that reduced levels of soil erosion result in reduced sedimentation.

1142.1 Southern States

115 Thirty BMP effectiveness studies from 1985 to 2015 were reviewed and documented by state

116 and physiographic region for the Southern US (Figure 1). The majority of effectiveness studies

117 were conducted in the Coastal Plain and Piedmont regions since these physiographic regions

118 have extensive areas of intensively managed forests and highly mechanized forest operations

119 (Allen et al., 2005; Fox, 2000). The BMP effectiveness studies reviewed in the South varied by

120 organization conducting the study (academia, state agency(s), federal agency(s), and industry), 
121 location, included assessment of evaluations and treatments, and offered key major conclusions 122 (Table 1).

\section{$123 \quad 2.1 .1 \quad$ Academia}

124 Twenty-two of the thirty reviewed studies were conducted by academia. The studies were

125 divided into five categories depending on study topic (water quality, SMZ, forest roads, skid

126 trails, and stream crossings).

$127 \quad$ 2.1.1.1 Water Quality

128 Arthur et al. (1998) studied the effects of BMPs on stream water quality in Appalachian Plateau

129 region of eastern Kentucky. Their study included two treatment watersheds (with BMPs and no

130 BMPs) and one reference watershed. The authors found that water yield, suspended sediment

131 flux, and concentrations of nitrate and other nutrients were higher on the no BMP watershed and

132 concluded that the BMP applied watershed which included a stream buffer strip reduced water

133 yield and sediment flux impacts.

134 Williams et al. (1999) evaluated the effectiveness of South Carolina BMPs on water quality in

135 the Piedmont physiographic region. Their study consisted of monitoring four experimental

136 watersheds on the Clemson Experimental Forest (3 treatment watersheds). Each treatment

137 watershed was harvested and site prepared (shear, rake and pile, herbicide and burn, and natural

138 regenerated) using South Carolina BMPs. The authors measured suspended sediment, nitrate,

139 phosphate, $\mathrm{pH}$, and water temperature and found that suspended sediments levels were 10 times

140 lower when BMPs were applied.

141 Wynn et al. (2000) evaluated the impacts on surface water quality from clearcutting and site

142 preparation in the Coastal Plain physiographic region of Virginia. Their study consisted of three

143 watersheds (clearcut without BMPs, clearcut with BMPs, and control). The no BMP watershed 
144 resulted in significant increases in storm event concentrations and loadings (sediment, nitrogen,

145 and phosphorus) following clearcutting and site preparation. The authors concluded that applying

146 BMPs during harvesting and site preparation can reduce the impacts of sediment and nutrients on

147 water quality.

148 Grippo and McCord (2006) conducted a bioassessment of Arkansas BMPs. The purpose of their

149 study was to evaluate the effectiveness of Arkansas's BMPs. They evaluated benthic

150 macroinvertebrates and physiochemical stream parameters (water temperature, dissolved oxygen,

151 conductivity, $\mathrm{pH}$, turbidity, nitrate and ortho-phosphate, and total suspended solids (TSS)) on

152 sites that were harvested and site prepared (ripped). The authors found that water quality

153 improved using Arkansas BMPs.

154 McBroom et al. (2008) studied the effects of intensive forest operations with BMPs on stream

155 water quality and runoff in the Coastal Plain region of Texas. Their study included two

156 treatments: conventional operation (clearcut with herbicide site preparation) and intensive

157 operation (clearcut with herbicide, subsoiling, and fertilization) and were compared to a previous

158 study on the same site without BMPs (Blackburn et al. 1986). The authors found reduced water

159 quality impacts when BMPs were applied for intensive forest operations.

160 DaSilva et al. (2013) assessed timber harvesting with BMPs on ecosystem metabolism in the

161 Coastal Plain physiographic region of Louisiana. Their study focused on calculating stream

162 metabolic rates to evaluate Louisiana BMPs. None of their calculated stream metabolic rates

163 were significant and the authors concluded that BMPs did not have a significant effect on stream

164 biology.

165 2.1.1.2 Streamside Management Zone (SMZ) 
166 Keim and Schoenholtz (1999) assessed the effectiveness of SMZs with intensive timber

167 harvesting in loessial bluff forests in the Coastal Plain of Mississippi. Their study had four

168 treatments: (1) unrestricted harvest with no buffer, (2) unrestricted outside of SMZ, cable only in

169 SMZ, (3) unrestricted harvest outside SMZ, no harvest in SMZ, and (4) reference. The authors

170 monitored water quality (TSS, turbidity, temperature, $\mathrm{pH}$, conductivity, and dissolved oxygen)

171 for 15 months post-harvest. Keim and Schoenholtz (1999) found that timber harvests without

172 SMZs resulted in three times the sediment concentration than the non-harvested watersheds.

173 They suggested eliminating equipment traffic near the stream (at least $10 \mathrm{~m}$ ). Carroll et al.

174 (2004) conducted a similar study to Keim and Schoenholtz (1999) within the sand-clay hills in

175 the Coastal Plain region of Mississippi. Their study had three treatments: (1) reference, (2)

176 clearcut with a SMZ, and (3) clearcut without a SMZ. The authors concluded that SMZs were

177 effective in protecting water quality, as their data showed similar responses between the SMZ

178 treatment streams and the reference streams for water quality, stream habitat indicators, and

179 aquatic macroinvertebrate communities.

180 Rivenbark and Jackson (2004) evaluated the frequency of SMZ breakthroughs for the Piedmont

181 physiographic region of Georgia to determine BMP efficiency. This study examined 30 clearcut

182 and site prepared sites for breakthroughs and successes. The authors defined breakthroughs as

183 where sediment entered the SMZ and entered the stream while successes were when the SMZ

184 stopped the sediment from entering the stream. They found 187 breakthroughs on 2,773 acres

185 which was then calculated to a breakthrough every 20 acres. The authors reported that $50 \%$ of

186 breakthroughs were due to gullies and swales and that roads or skid trails caused $25 \%$ of

187 breakthroughs. A similar study was conducted by Lang et al. (2015) but for the Virginia

188 Piedmont. The authors used similar terminology and definitions but used the term partial 
189 breakthroughs instead of successes and complete breakthroughs for breakthroughs. They found 19033 complete breakthroughs and 8 partial breakthroughs on $10 \mathrm{~km}$ of SMZs (16 sites), which 191 averaged one complete breakthrough every $0.3 \mathrm{~km}$ of SMZ length. Lang et al. (2015) found that

$19242 \%$ of breakthroughs were due to stream crossings, $27 \%$ from gullies, and $24 \%$ from soil

193 disturbances from timber harvesting within the SMZ.

194 Ward and Jackson (2004) evaluated SMZ sediment trapping efficiency for sites that were 195 clearcut, site prepared (mechanical and chemical), and replanted in the Georgia Piedmont. Their 196 study had two treatments: (1) SMZ and (2) no SMZ. The authors placed a silt fence at the edge 197 of the SMZ to accomplish the no SMZ treatment. SMZs trapped sediment from overland flow $19881 \%$ of the time. Ward and Jackson (2004) also estimated that the sediment delivery ratio was $19925 \%$ for their sites by taking their measured sediment from treatment two and compared it to 200 Revised Universal Soil Loss Equation (RUSLE) predictions. Lakel et al. (2010) conducted a 201 similar study evaluating SMZs sediment trapping ability for harvested and site prepared sites in 202 the Virginia Piedmont. The authors compared sediment trapping of different SMZ widths and 203 thinning levels (30.4 m, $15.2 \mathrm{~m}, 7.6 \mathrm{~m}$, and $15.2 \mathrm{~m}$ thinned) and found that SMZs efficiency for 204 trapping sediment ranged from $84 \%$ to $97 \%$. Lakel et al. (2010) found the sediment delivery 205 ratios between $3 \%$ and $14 \%$.

206 Witt et al. (2013) evaluated the effectiveness of different SMZ treatments for ephemeral streams 207 in the Cumberland Plateau of Kentucky. The treatments applied in this study were: (1) harvest, 208 unimproved stream crossing, and no SMZ, (2) harvest, retention of only channel bank trees, and 209 improved stream crossing, (3) harvest with 7.6 m SMZ and an improved stream crossing, and (4) 210 control (no harvest). The authors collected water samples (TSS, turbidity, settleable solids, and 211 sediment transport rate) and found that treatment two and treatment three resulted in significantly 
212 lower TSS and turbidity levels than treatment one (no SMZ). Treatment three was not

213 significantly different than the control for TSS while treatment two was significantly different

214 than the control (4) for both TSS and turbidity.

\section{$215 \quad$ 2.1.1.3 Forest Roads}

216 Forest roads tend to be one of the major sources of sediment from forest operations. Appelbloom

217 et al. (2002) assessed forest road practices for reducing sediment loss from forest roads in the

218 Coastal Plain of North Carolina. The authors evaluated the effectiveness of seven road practices

219 and collected runoff samples. The road practices consisted of one continuous berm treatment and

220 six non-continuous berm treatments (berm with drainage breaks). Appelbloom et al. (2002) noted

221 that the continuous berm treatment reduced sediment loss by $99 \%$ when compared to the road

222 not having a continuous berm. The authors also found that graveling a road can reduce sediment

223 loss by $61 \%$ when a continuous berm is used and a grass strip $(90 \mathrm{~cm})$ can reduce sediment loss

224 by $56 \%$ when compared to a road without a grass strip.

225 Turton et al. (2009) evaluated the effectiveness of BMPs for reducing sediment from unpaved

226 roads in the Stillwater Creek Watershed in Oklahoma. The authors evaluated sediment yield and

227 runoff on four rural unpaved road segments. They had two treatments and a control; treatments

228 included: (1) widened and reshaped ditches, reshaped cut slopes, crowning of road surface, and

229 vegetating disturbed areas and (2) crowning the road surface, geo-synthetic fabric, and $127 \mathrm{~mm}$

230 gravel. Turton et al. (2009) found that BMPs significantly reduced sediment yields.

231 Brown et al. (2013) assessed sediment delivery from bare and graveled stream approaches in the

232 Virginia Piedmont. They trapped sediment from five re-graded legacy forest road stream

233 approaches and compared them to four graveled forest road stream approaches. The authors

234 found bare ground stream approaches produced sediment delivery rates 7.5 times greater (34 to 
$235287 \mathrm{Mg} \mathrm{ha}^{-1} \mathrm{y}^{-1}$ ) than graveled road approaches (10 to $16 \mathrm{Mg} \mathrm{ha}^{-1} \mathrm{y}^{-1}$ ). Brown et al. (2013) noted

236 that lack of both road surface cover and sufficient water control structures resulted in higher

237 rates.

238 Brown et al. (2014) studied the effects of increasing gravel cover on forest roads to reduce

239 sediment delivery to stream crossings on reopened legacy forest road stream crossings in the

240 Virginia Piedmont. Their study had three stream approach treatments: (1) no gravel, (2) low

241 gravel, and (3) high gravel. The authors reported higher median surface runoff TSS

242 concentrations for no gravel treatments $\left(2.84 \mathrm{~g} \mathrm{l}^{-1}\right)$, followed by low gravel treatments $\left(1.10 \mathrm{~g} \mathrm{l}^{-}\right.$

$\left.243^{1}\right)$, and high gravel $\left(0.82 \mathrm{~g} \mathrm{l}^{-1}\right)$. They noted that reopened and unsurfaced stream crossing

244 approaches can produce significant runoff and deliver sediment to streams; however, applying

245 BMPs to the approaches significantly reduced sediment.

$246 \quad$ 2.1.1.4 Skid Trails

247 Sawyers et al. (2012) assessed erosion control effectiveness of five overland skid trail closure

248 methods in the Piedmont physiographic region of Virginia. Their closure treatments included: (1)

249 waterbar only, (2) waterbar with seed, (3) waterbar with seed and mulch, (4) waterbar with

250 hardwood slash, and (5) waterbar with pine slash. The authors measured trapped sediments and

251 predicted erosion using the Universal Soil Loss Equation (USLE-Forest) and the Water Erosion

252 Prediction Project (WEPP-Roads). Waterbar with seed and mulch treatments had the lowest

253 erosion rate (3.3 $\left.\mathrm{Mg} \mathrm{ha}^{-1} \mathrm{y}^{-1}\right)$ followed by waterbar with hardwood slash (5.1 $\left.\mathrm{Mg} \mathrm{ha}^{-1} \mathrm{y}^{-1}\right)$,

254 waterbar with pine slash (5.4 $\left.\mathrm{Mg} \mathrm{ha}^{-1} \mathrm{y}^{-1}\right)$, waterbar with seed (13.6 $\left.\mathrm{Mg} \mathrm{ha}^{-1} \mathrm{y}^{-1}\right)$, and waterbar

255 only (24.2 $\left.\mathrm{Mg} \mathrm{ha}^{-1} \mathrm{y}^{-1}\right)$. WEPP predicted similar erosion estimates to the measured data. Wade et

256 al. (2012) conducted a similar study to Sawyers et al. (2012) in assessing erosion control

257 effectiveness of five bladed skid trail closure techniques in the Virginia Piedmont. Their 
treatments were the same as Sawyers et al. (2012) and also measured trapped sediment and

259 modeled erosion. Wade et al. (2012) also found that the waterbar with seed and mulch treatment

260 had the best erosion control (3.0 $\left.\mathrm{Mg} \mathrm{ha}^{-1} \mathrm{y}^{-1}\right)$ followed by waterbar with pine slash (5.9 $\mathrm{Mg} \mathrm{ha}^{-1}$

$\left.261 \mathrm{y}^{-1}\right)$, waterbar with hardwood slash $\left(8.9 \mathrm{Mg} \mathrm{ha}^{-1} \mathrm{y}^{-1}\right)$, waterbar with seed $\left(31.5 \mathrm{Mg} \mathrm{ha}^{-1} \mathrm{y}^{-1}\right)$, and

262 waterbar only $\left(137.7 \mathrm{Mg} \mathrm{ha}^{-1} \mathrm{y}^{-1}\right)$.

263 Wear et al. (2013) studied the effectiveness of BMPs in reducing sediment on operational

264 temporary skid trail stream crossings in the Virginia Piedmont. The authors applied three BMP

265 closure treatments on stream crossing approaches after steel bridges were removed: (1) slash, (2)

266 mulch and seed, and (3) mulch, seed, and silt fence. They sampled water quality upstream and

267 downstream for TSS and found slash (1) and mulch with seed treatments (2) reduced TSS, while

268 mulch, seed, and silt fence (3) increased TSS. The authors attributed increases in TSS from

269 treatment three to soil disturbance near the stream from silt fence installation.

\section{$270 \quad$ 2.1.1.5 Stream Crossings}

271 Aust et al. (2011) evaluated the effects of four operational forest stream crossings (portable steel

272 skidder bridge, culverts with poles as fill material, culverts with earth as fill material, and

273 reinforced ford) in the Piedmont physiographic region of Virginia. The authors examined 23

274 operational stream crossings and approaches during four phases (initial, install, harvest, and

275 closure) and measured total dissolved solids, $\mathrm{pH}$, conductivity, temperature, and sediment

276 concentration. They found culvert crossing approaches resulted in the highest erosion rates and

277 that bridge crossing had the least effects on water quality. Additionally, the install and harvest

278 phases had the greatest effect on water quality and concluded that BMPs should be followed

279 during all phases. 
Morris et al. (2015) assessed the effectiveness of BMPs for stream crossings (permanent bridge,

281 culvert, and improved ford) in reducing sediment for the Virginia Piedmont. Their study

282 implemented a rainfall simulation to evaluate different rainfall intensities (low: 0.5 to 1.0 inches

283 per hour, medium: 1.5 to 2.0 inches per hour, and high: 2.0 to 2.5 inches per hour). The rainfall

284 simulations were conducted on three BMP treatment levels: (1) minimal BMP erosion control,

285 (2) BMP erosion control from the Virginia BMP Manual, and (3) erosion control exceeding what

286 Virginia recommends. The culvert crossing produced $2.9 \mathrm{~g} / \mathrm{L}$ of sediment concentration, while

287 the ford produced $1.4 \mathrm{~g} / \mathrm{L}$ and the bridge produced $0.2 \mathrm{~g} / \mathrm{L}$. They concluded that Virginia BMP

288 guidelines were effective.

$289 \quad 2.1 .2 \quad$ State

290 Forestry BMP monitoring effectiveness was the main focus of the studies reviewed in the

291 southern US. Adams et al. (1995) assessed the effectiveness of South Carolina BMPs by

292 evaluating if biomonitoring can be used as a measure of determining BMP effectiveness. The

293 authors conducted a BMP compliance check, stream habitat assessment, and a benthic

294 macroinvertebrate bioassessment on 27 harvested sites. Adams et al. (1995) found that

295 assessments of stream habitat and benthic macroinvertebrates were an effective approach in

296 determining BMP effectiveness.

297 Vowell (2001) conducted a similar study that determined if stream bioassessments could be used

298 to monitor BMP effectiveness on intensively managed forests in Florida. He determined a stream

299 condition index (SCI) at each site before silvicultural treatments then conducted stream

300 bioassessments after the treatments were applied. The author found no significant differences in

301 the SCI and concluded that Florida recommended BMPs were effective in protecting water

302 quality in intensively managed forests. Vowell and Frydenborg (2004) built on the study 
303 conducted by Vowell (2001), the authors evaluated intensively managed sites that included

304 chemical applications. No significant differences in SCI were found, indicating that BMPs were

305 effective in protecting water quality in intensively managed forests with chemical applications.

306 Simpson et al. (2008) evaluated the effectiveness of Texas BMPs on intensively managed

307 silvicultural operations. The authors conducted water quality monitoring (biological and

308 physiochemical) on four perennial streams over a four year period. They concluded that the

309 proper application of Texas BMPs resulted in effectively protecting water quality.

$310 \quad 2.1 .3 \quad$ Federal

311 Three studies conducted by the US Forest Service were reviewed for the southern region. Mc

312 Clurkin et al. (1985) evaluated water quality from clearcutting loblolly pine plantations on

313 erosive soils in the upper Gulf Coastal Plain of Tennessee. The authors evaluated stormflow

314 exports of sediment and nutrients on eight catchments and concluded that clearcutting did not

315 cause a significant impact on water quality as long as proper practices were applied.

316 Clinton (2011) evaluated riparian buffer width effectiveness by evaluating stream water quality

317 in the Blue Ridge physiographic region of western North Carolina. The author examined cable

318 yarding harvesting on three riparian buffer treatments $(0 \mathrm{~m}, 10 \mathrm{~m}$, and $30 \mathrm{~m})$. Water quality

319 measurements (chemistry, temperature, and TSS) were sampled on three of four catchments. The

$3200 \mathrm{~m}$ buffer site had increased stream nitrate concentrations and summer water temperatures, and

321 TSS levels remained unchanged. Ten and $30 \mathrm{~m}$ buffer treatments reduced TSS levels. Clinton

322 (2011) concluded that the $10 \mathrm{~m}$ buffer was efficient in protecting water quality.

323 Grace and Elliot (2011) assessed the effectiveness of forest road BMPs by evaluating storm

324 runoff and sediment loading. Their study was conducted over a six year period in northeast

325 Georgia (Chattahoochee-Oconee National Forest) and included three sediment control treatments 
326 (hay bale barrier, sediment basin, and sediment basin with riser control). The authors found that

327 the sediment basin with riser control had the highest mean sediment trapping efficiency (99\%),

328 followed by hay bale barrier (97\%), and sediment basin (94\%). However, no significant

329 differences were found between treatments. The authors concluded that sediment transport was

330 reduced for all three treatments.

$331 \quad 2.1 .4$ Industry

332 We reviewed one industry study in the southern region conducted by International Paper

333 (Ruhlman 1999). Ruhlman (1999) evaluated the effectiveness of forestry BMPs on intensively

334 managed watersheds near the upper Coastal Plain and Piedmont physiographic border in

335 Georgia. The author assessed water quality (chemical sampling of sediment and nutrients and

336 benthic macroinvertebrates) on a treatment watershed of 780 acres and a reference watershed of

337351 acres. The treatment watershed had an 80 foot SMZ that was selective cut. Ruhlman (1999)

338 did not find significant differences in chemical sampling and benthic macroinvertebrate samples

339 and concluded properly applied forest BMPs protected water quality. 


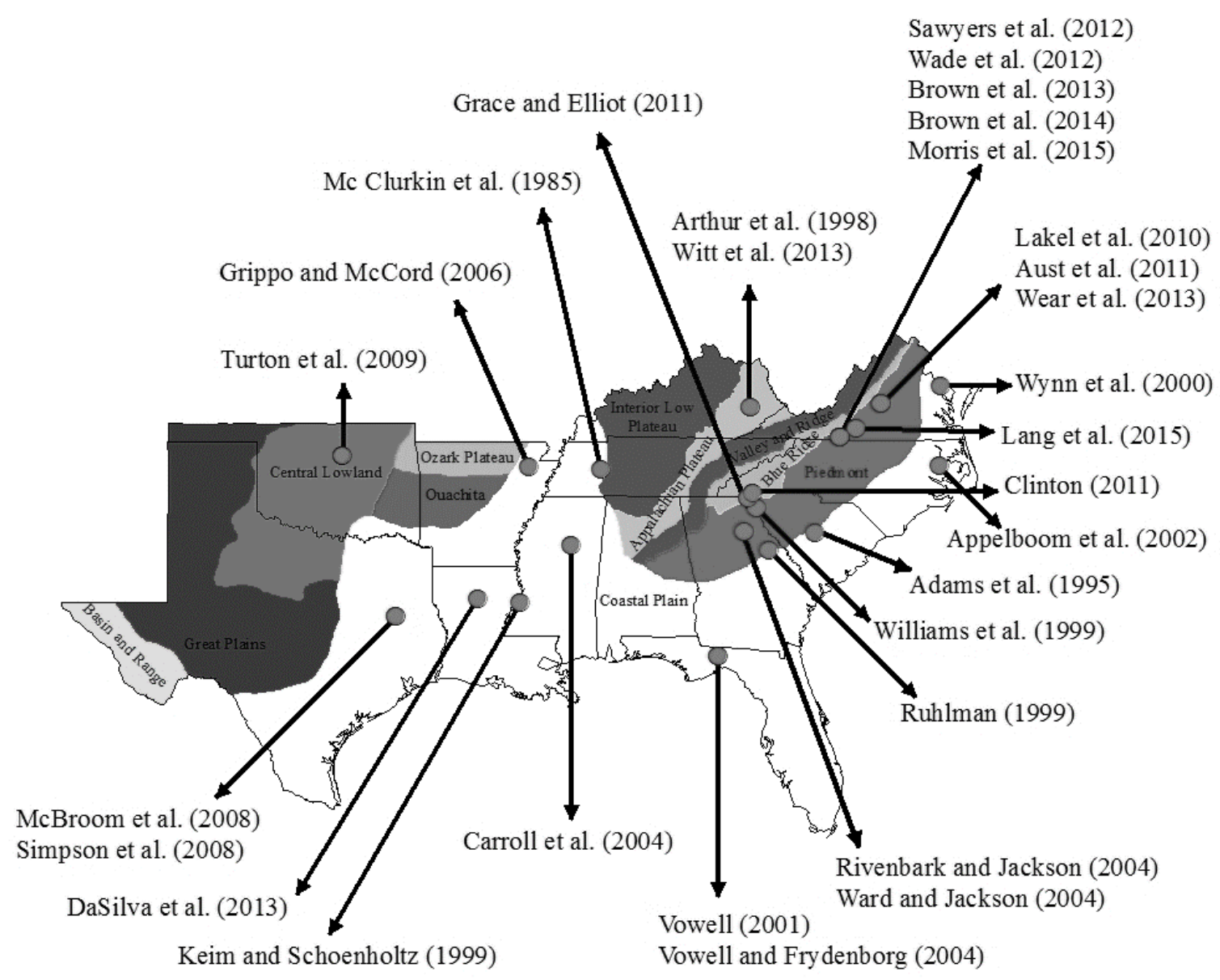

341 Figure 1. Reviewed BMP effectiveness studies by state and physiographic region for the 342 southeastern United States. Locations were determined from the studies as well as Schilling 343 and Ice (2012). 

and treatments, and major conclusions.

\begin{tabular}{lllll}
\hline Investigators & $\begin{array}{l}\text { Region/ } \\
\text { Location }\end{array}$ & $\begin{array}{l}\text { Study } \\
\text { conducted } \\
\text { by }\end{array}$ & Evaluations/treatments & Major conclusions \\
\hline $\begin{array}{l}\text { Mc Clurkin } \\
\text { et al. (1985) }\end{array}$ & $\begin{array}{l}\text { Upper Gulf } \\
\text { Coastal Plain } \\
\text { (Tennessee) }\end{array}$ & Federal & $\begin{array}{l}\text { Clearcutting pine plantations on fragile soils } \\
\text { of abandoned agricultural land }\end{array}$ & $\begin{array}{l}\text { Clearcutting pine plantations on } \\
\text { fragile soils can be accomplished } \\
\text { without significant impact on water } \\
\text { quality if the proper forest practices } \\
\text { are applied }\end{array}$ \\
& & & $\begin{array}{l}\text { abed } \\
\text { and }\end{array}$
\end{tabular}

Adams et al. South Carolina State (1995)

Arthur et al. Kentucky (1998)

$\begin{array}{ll}\text { Keim and } & \text { Mississippi } \\ \text { Schoenholtz } & \text { Bluff Hills Gulf } \\ \text { (1999) } & \text { Coastal Plain }\end{array}$

Ruhlman Upper Coastal Industry (1999)
Compared state BMP compliance results with stream bio-assessments of benthic macroinvertebrates and stream habitats

Academia

Effects of BMP implementation on stream water quality; evaluated suspended sediment flux, water yield, and concentrations of nutrients

Academia

Effectiveness of SMZs on loessial bluff forests; evaluated stream total suspended solids (TSS), turbidity, temperature, $\mathrm{pH}$, conductivity, and dissolved oxygen

Effectiveness of forestry BMPs on intensively managed watersheds
Assessment of stream macroinvertebrates and stream habitat were an effective approach of determining BMP effectiveness

Forestry BMPs were effective; buffer strips were effective in reducing water yield and sediment flux on clearcuts

SMZs were effective in reducing overland flow and TSS concentrations due to the forest floor near the stream and stream channels not being disturbed

Forestry BMPs were effective in protecting water quality 


\section{Williams et Piedmont \\ al. (1999) \\ (South \\ Carolina)}

Wynn et al. Coastal Plain

(2000) (Virginia)

Academia

Effects of timber harvesting and site preparation BMPs on surface water quality

$\begin{array}{ll}\text { Vowell } & \begin{array}{l}\text { Coastal Plain } \\ \text { (Florida) }\end{array}\end{array}$

Appelboom Coastal Plain

et al. (2002) (North

Carolina)
Academia

Effectiveness of South Carolina BMPs for

harvesting and site preparation
Evaluated if stream bio-assessment could be used to monitor forestry BMPs for intensive silviculture activities

Academia Forest road practices for sediment reduction

Suspended sediments were lower on sites that applied BMPs

BMPs for timber harvesting and site preparation in the Coastal Plain region significantly reduced sediment when compared to not applying BMPs

Stream condition index (SCI) was not significantly different between the reference data and treatment data; correctly implemented BMPs applied to areas around streams provide protection to stream ecosystems

Found that a continuous berm along the edge of a forest road reduced sediment by an average of $99 \%$, gravel reduced sediment by an average of $61 \%$, and a grass strip reduced sediment by an average of $56 \%$; sedimentation from Coastal Plain roads can be reduced with appropriate forest road BMPs

Academia Effectiveness of SMZs on clearcut harvests; assessed water quality, mineral soil exposure, net deposition and erosion that entered the SMZs, stream habitat indicators, and aquatic macroinvertebrates

Found a significant increase in stream temperature and macroinvertebrate density and a decrease in habitat stability when SMZs were absent; concluded that SMZs can be effective in protecting water quality 


\section{Rivenbark Piedmont and Jackson (Georgia) (2004)}

\section{Vowell and Coastal Plain Frydenborg (Florida) \\ (2004)}

$\begin{array}{ll}\text { Ward and } & \text { Piedmont } \\ \text { Jackson } & \text { (Georgia) }\end{array}$

(2004)

Grippo and Arkansas
McCord
(2006)

McBroom et Western Gulf al. (2008)
Academia

Efficiency of BMPs with preventing overland flow and sediments from reaching waterways; assessed SMZ breakthroughs (failures) on sites that were clearcut and site prepared

State

Supplemented Vowell (2001) study assessing stream bio-assessments for evaluating the effectiveness of forestry BMPs with the addition of chemical applications

Academia Effectiveness of SMZs for reducing sediment transport from concentration overland flow on two clearcuts that applied mechanical and chemical site preparation and planting

Academia

Effectiveness of Arkansas BMPs adjacent to timber harvests; bio-assessment of benthic macroinvertebrates and water quality

Academia

Storm runoff and sediment loss associated with clearcutting and stand establishment (intensive and conventional site preparation) with BMPs
Roughly $50 \%$ of all breakthroughs were due to gullies and swales; runoff from forest roads and skid trails caused $25 \%$ of all breakthroughs; SMZ widths should be based on site features

Their conclusions were similar to the previous study in that BMPs applied to areas around streams provide protection to stream ecosystems during intensive silviculture activities including chemical applications

Estimated the sediment delivery ratio was $25 \%$; SMZs were effective for trapping sediment from concentrated overland flow with an average of $81 \%$ efficiency

Water chemistry and benthic macroinvertebrates were not affected by timber harvesting where BMPs were applied

First year sediment loss was significantly lower than if BMPs were not applied 


\begin{tabular}{|c|c|c|c|}
\hline $\begin{array}{l}\text { Simpson et } \\
\text { al. }(2008)\end{array}$ & Texas & State & $\begin{array}{l}\text { Effectiveness of Texas forestry BMPs } \\
\text { (2003-2007) on four perennial streams that } \\
\text { had intensive forestry practices; monitored } \\
\text { biological and physiochemical stream } \\
\text { conditions }\end{array}$ \\
\hline $\begin{array}{l}\text { Turton et al. } \\
\text { (2009) }\end{array}$ & $\begin{array}{l}\text { Stillwater Creek } \\
\text { Watershed } \\
\text { (Oklahoma) }\end{array}$ & Academia & $\begin{array}{l}\text { Effectiveness of BMPs in reducing } \\
\text { sediment from unpaved roads; evaluated } \\
\text { runoff and sediment yield; treatments } \\
\text { included: (1) control, (2) widened ditches, } \\
\text { reshaped ditches, cut slopes, crowning of } \\
\text { road surface, and vegetating disturbed areas, } \\
\text { and (3) crowning of road surface, geo- } \\
\text { synthetic fabric on road bed, and } 127 \mathrm{~mm} \\
\text { gravel }\end{array}$ \\
\hline
\end{tabular}

Lakel et al. Piedmont

(2010) (Virginia)
Academia

Effects of SMZ widths and thinning levels on sediment moving through SMZs; SMZ treatments included widths of: $30.4 \mathrm{~m}, 15.2$ $\mathrm{m}$, and $7.6 \mathrm{~m}$ without thinning and $15.2 \mathrm{~m}$ with thinning; calculated sediment delivery ratio; second study (sub-watersheds)

evaluated sediment at site preparation areas, fire lines, and streams; BMPs were followed on the study sites
No significant differences in pretreatment and post-treatment conditions; concluded that properly applied BMPs are effective in protecting water quality

Sediment yields were significantly reduced after application of both BMP treatments; Treatment 2 had a $20 \%$ reduction in sediment yield and treatment 3 had an $80 \%$ reduction in sediment yield when compared to no BMPs applied (control treatment)

Did not find any significant differences in sediment delivery for all SMZ treatments; second study found significant difference in sediment from the harvest, fire line, and SMZ treatment; fire lines produced 12 times more sediment as the harvest with a sediment delivery ratio of $14 \%$; overall SMZs trapped between $84 \%$ to $97 \%$ of the erosion 


\section{Aust et al. Piedmont \\ (Virginia)}

Academia

Effects of operational forest stream crossings had on water quality; treatments included: (1) portable steel skidder bridge, (2) culvert with poles as fill material, (3) reinforced ford, and (4) culvert with earth as fill material; assessed total dissolved solids, $\mathrm{pH}$, conductivity, temperature, and sediment concentrations prior to installations, after installation, during harvest, and after road closure

$\begin{array}{lll}\text { Clinton } & \begin{array}{l}\text { Blue Ridge } \\ \text { (Western North }\end{array} & \text { Federal } \\ \text { Carolina) } & \end{array}$

Grace and Northeast

Elliot (2011) Georgia temperature, and TSS

Effectiveness of forest road BMPs in controlling sediment movement; treatments
The authors found that the bridge stream crossings had the least effects on water quality and the culvert had the highest estimated erosion potentials; concluded that appropriate BMPs should be followed during all periods of a timber harvest rather than waiting until closing the site to implement BMPs

Concluded that riparian buffers $10 \mathrm{~m}$ and wider minimized impacts on stream water quality and provide an effective method to protect water quality included: (1) hay bale barrier, (2) sediment basin, and (3) sediment basin with riser control
Mean sediment trapping efficiency was $99 \%$ for the sediment basin with a riser control, $97 \%$ for the hay bale barrier, and $94 \%$ for the sediment basin; No significant differences in sediment trapping efficiency; sediment control structures reduced runoff by greater than $98 \%$ and sediment delivery between 94 and $97 \%$ 
$\begin{array}{ll}\text { Sawyers et } & \text { Piedmont } \\ \text { al. (2012) } & \text { (Virginia) }\end{array}$

Wade et al. Piedmont

(2012) (Virginia)

$\begin{array}{ll}\text { Witt et al. } & \text { Cumberland } \\ \text { (2013) } & \text { Plateau } \\ & \text { (Kentucky) }\end{array}$

\section{Wear et al. Piedmont (2013) (Virginia)}

Academia

SMZ effectiveness on ephemeral streams; four treatments: (1) no SMZ, (2) SMZ with no limitations, (3) SMZ with limitations, and (4) control; unimproved and improved stream crossings were used; sampled TSS, turbidity, and sediment transport rate

Academia

Effectiveness and implementation costs of overland skid trail closure techniques within an 11.7 ha clearcut; treatments included: (1) waterbar only, (2) waterbar with seed, (3) waterbar with seed and mulch, (4) waterbar with hardwood slash, and (5) waterbar with pine slash; assessed sediment loss

Academia Compared five erosion control techniques on bladed skid trails; treatments included:

(1) waterbar only, (2) waterbar with seed,

(3) waterbar with seed and mulch, (4) waterbar with hardwood slash, and (5) waterbar with pine slash

\section{Effectiveness of BMPs for reducing}

sediment at operational steel bridge stream crossings; skid trail stream approaches included three treatments: (1) slash, (2) mulch and grass seed, and (3) mulch, grass seed, and silt fence; sampled TSS
Academia
Found that the mulch treatment (3.3 $\left.\mathrm{Mg} \mathrm{ha}^{-1} \mathrm{y}^{-1}\right)$ was the most effective method in reducing erosion followed by hardwood slash $\left(5.1 \mathrm{Mg} \mathrm{ha}^{-1} \mathrm{y}^{-1}\right)$, pine slash (5.4 Mg ha $\left.{ }^{-1} \mathrm{y}^{-1}\right)$, seed (13.6 Mg ha $\left.\mathrm{y}^{-1}\right)$, and control $(24.2$ $\mathrm{Mg} \mathrm{ha}^{-1} \mathrm{y}^{-1}$ )

Similar results to Sawyers et al. (2012) in that the waterbars with mulch treatment was the least erosive followed by the slash treatment; concluded that applying mulch and slash provide good erosion control

Both SMZ treatments significantly lowered TSS and turbidity when compared to the no SMZ treatment; When compared to control, treatment 2 resulted in higher TSS and turbidity while treatment 3 resulted in no difference in TSS; concluded that improved stream crossings significantly lower stream TSS and turbidity

Both slash and mulch with grass seed treatments effectively reduced TSS and the silt fence treatment increased TSS due to soil disturbance from installation 
Brown et al. Piedmont

(2013) (Virginia)

\section{DaSilva et Gulf Coast \\ al. (2013) \\ Plain \\ (northcentral \\ Louisiana)}

\begin{abstract}
Brown et al. Piedmont
(2014) (Virginia)
\end{abstract}

\section{Lang et al.}

(2015)
Academia

Sediment delivery from bare and graveled stream approaches; compared road derived trapped sediment on five re-graded bare legacy stream approaches to four graveled approaches

Academia

Stream metabolic rates to test the effects of timber harvesting with Louisiana BMPs; sampled dissolved oxygen, water temperature, and stream depth above and below a timber harvest of loblolly pine

\section{Academia}

Effect of increasing gravel cover on forest roads to reduce sediment delivery to stream crossings; reopening of legacy forest road stream crossings; treatments included: (1) no gravel, (2) low gravel, and (3) high gravel

$$
\begin{aligned}
& \text { Piedmont } \\
& \text { (Virginia) }
\end{aligned}
$$

Academia

Identified and characterized SMZ

breakthroughs (partial and complete) by frequency and potential causes for $10 \mathrm{~km}$ of SMZs
Sediment delivery for the bare approaches were 7.5 times higher (34 to $287 \mathrm{Mg} \mathrm{ha}^{-1} \mathrm{y}^{-1}$ ) than the gravel road approaches (10 to $16 \mathrm{Mg} \mathrm{ha}^{-1} \mathrm{y}$ $\left.{ }^{1}\right)$; concluded that sediment delivery rates were due to inadequate road surface cover and water control structures and that proper BMPs such as gravel and appropriate spacing of water control structures can reduce sediment

Calculated metabolic rates and none of the results were significantly changed from the timber harvest; concluded that similar timber harvests applied with Louisiana BMPs should not significantly change stream biological conditions

Reopened and unsurfaced stream crossing approaches may produce significant sediment delivery and surface runoff into streams and that low cost BMPs can be used to protect water quality when reopening forest roads

Found 33 complete breakthroughs and 8 partial breakthroughs over 16 sites, averaging 1 complete breakthrough every $0.3 \mathrm{~km} ; 42 \%$ of 
Morris et al. Piedmont

(2015)
(Virginia)
Academia

Effectiveness of stream crossing BMPs for sediment control (bridge, culvert, ford); three treatments: (1) minimal BMP erosion control (low), (2) BMP erosion control recommended by the Virginia BMP Manual (medium), and (3) erosion control exceeding the Virginia BMP Manual recommendations (high) complete breakthroughs were from stream crossings, $27 \%$ from reactivation of legacy agricultural gullies, and 24\% from harvest related soil disturbances

Found that the culvert stream crossing produced double the sediment concentration $(2.9 \mathrm{~g} / \mathrm{L})$ than the ford $(1.4 \mathrm{~g} / \mathrm{L})$ and ten times more than the bridge $(0.2 \mathrm{~g} / \mathrm{L})$; current Virginia BMPs were effective in reducing sedimentation 
347 BMP effectiveness studies in the northern US take place primarily in the northeastern and lake

348 state regions (Figure 2). Effectiveness studies across the Northern states cover a range of

349 different physiographic regions. Twenty effectiveness studies from 1963 to 2014 were reviewed

350 by organization conducting the study: academia (6), federal (6), state (6), and non-profit (2)

351 (Table 2).

$352 \quad 2.2 .1 \quad$ Academia

$353 \quad$ 2.2.1.1 Water Quality

354 Lynch et al. (1985) studied BMPs for controlling NPSP in the Ridge and Valley physiographic

355 region of central Pennsylvania. Their study included three treatment watersheds: (1) commercial

356 clearcut, (2) clearcut with herbicide, and (3) control. The authors evaluated stream chemistry,

357 turbidity, sediment concentrations, water temperature, and nutrient concentrations. Lynch et al.

358 (1985) found small increases in turbidity and sediment concentrations and suggested these

359 increases were due to erosion caused by windblown trees located along the intermittent stream

360 channel. The authors concluded that BMPs were effective and that a buffer strip might have

361 helped reduce windblown trees along the stream channel.

362 Lynch and Corbertt (1990) evaluated the effectiveness of BMPs from long-term (15-year)

363 streamflow and water quality data in the Ridge and Valley of central Pennsylvania. Their study

364 was a paired watershed on the Leading Ridge Experimental Watershed Research Unit which

365 consisted of a 303 acre control watershed and a 257 acre treatment watershed (110 ac clearcut).

366 The authors found significant, however relatively small, increases at two years post-harvest in

367 nitrate and potassium concentrations, stream temperature, and turbidity. The authors also found

368 that by year four post-harvest, water yields returned to pre-harvest levels. Lynch and Corbertt 
(1990) concluded that BMPs were effective due to no serious altercations of water quality and

370 suggested buffer strips on intermittent streams, increases in buffer strip width, and post-harvest

371 site inspections.

372 Passhaus et al. (2004) sampled macroinvertebrates populations in ephemeral streams pre-harvest

373 and post-harvest. Their study was a paired watershed (treatment and control) study in the

374 Catskills of southern New York. The treatment watershed was thinned (60\% of the basal area).

375 The authors did not find any significant impacts on macroinvertebrate populations from the

376 thinning operation.

377 Chizinski et al. (2010) evaluated the response of macroinvertebrate and fish communities to

378 partial harvesting stream buffers on four small streams located in the Superior Upland

379 physiographic region of northern Minnesota. Their study included three treatments: (1) control,

380 (2) clearcut with no harvesting in stream buffer, and (3) clearcut with harvesting within stream

381 buffer. The authors conducted sampling one year pre-harvest and then for three years post-

382 harvest. Chizinski et al. (2010) found few effects in partial harvesting stream buffers for

383 macroinvertebrate communities and did not find any significant changes in fish communities.

384 They concluded that timber can be harvested to a certain degree in stream buffers.

385 2.2.1.2 BMP Implementation

386 Schuler and Briggs (2000) examined the application and effectiveness of New York BMPs. Their

387 study evaluated 42 BMP guidelines for roads, landings, skid trails, equipment, and buffer strips

388 on 114 harvested sites in the Catskills (61) and Adirondacks (53). The authors reported BMP

389 application was $78 \%$ for roads, $87 \%$ for landings, $59 \%$ for skid trails, $88 \%$ for equipment, and

$39073 \%$ for buffer strips. Applying BMPs decreased sediment movement, while failure to properly

391 apply BMPs resulted in lower effectiveness measures. 
392 Germain and Munsell (2005) assessed surface area disturbance from forest roads, skid trails, and

393 landings (harvest access systems) in the Catskills of New York. The authors mailed a survey to

394 landowners who conducted recent timber harvesting and visited sites where permission was

395 granted. The authors used a modified BMP site evaluation from Schuler and Briggs (2000). Their

396 site evaluation included surface area disturbance measurements of landings, roads, skid trails,

397 stream crossings (roads and skid trails) on 43 sites. Germain and Munsell (2005) found low

398 surface area disturbance does not always result in high BMP implementation.

$399 \quad 2.2 .2 \quad$ State

400 Pannill et al. (2000) evaluated the effectiveness of Maryland's BMPs on a paired watershed 401 study that incorporated a control watershed and a partially harvested watershed. The authors

402 sampled TSS, stormflow, stream temperature, and macroinvertebrates and found no significant

403 differences between the pre-harvest period and post-harvest treatment. They concluded that

404 properly implemented BMPs will help protect stream water quality, biology, and habitat.

405 Wisconsin officially published their first BMP manual in 1995 when their water quality program

406 was developed. Wisconsin DNR (2006) assessed the first ten years of their water quality

407 program (1995-2005). They found the average BMP compliance was 83\% over that time period

408 and that BMP effectiveness was 99\% when the adequate BMPs were applied. Wisconsin DNR

409 (2006) reported that when BMPs were not followed, water quality was impacted $71 \%$ of the

410 time.

411 Wang and Goff (2008) assessed the application and effectiveness of West Virginia BMPs. The

412 authors selected a sample of 33 harvested sites with SMZs from a previous survey of 116 sites.

413 They evaluated 27 West Virginia BMP guidelines for forest roads, skid trails, landings, and

414 SMZs and found average effectiveness was $80 \%$ with an average application of $85 \%$. The 
415 authors also found industrial land or land that involved a professional forester resulted in

416 increased application and effectiveness scores.

417 The Maryland DNR (2009) evaluated implementation and effectiveness of Maryland's BMPs

418 from 2004 to 2005. Their study assessed BMPs on 75 forest harvested sites throughout the state.

419 The overall BMP implementation was $81 \%$ for all 75 sites and $81 \%$ for sites that had water

420 present. They found that BMPs were $77 \%$ effective in protecting water quality from sediment

421 delivery. The Maryland DNR (2009) also reported that 19\% of sites delivered measurable

422 sediment to waterways.

423 McCoy and Sobecki (2011) conducted a review of Indiana forestry BMP monitoring from 1996

424 to 2011. Indiana formed their first BMP guidelines in 1995 with their first monitoring conducted

425 in 1996. Over their 15 year review, 671 sites were monitored for BMP implementation and

426 effectiveness with an average BMP implementation rate of $86 \%$ and an average effectiveness

427 rate of $93 \%$. Stream crossing BMPs had the lowest rating for both effectiveness (79\%) and

428 implementation (74\%). The authors concluded that with a high overall effectiveness rating,

429 impacts to water quality from forest operations in Indiana is small.

430 The Maine FS (2014) assessed the implementation and effectiveness of Maine's forestry BMPs

431 in protecting water quality. Their study consisted of monitoring 101 harvested sites. Forestry

432 BMPs were $91 \%$ effective in protecting water quality from sediment. Stream crossings and

433 approaches had the proper BMPs on $83 \%$ of the crossings monitored. The Maine FS (2014)

434 stated that BMPs prevent sedimentation when implemented properly.

$435 \quad 2.2 .3 \quad$ Federal

436 Reinhart et al. (1963) evaluated the effects of timber harvesting on streamflow in West Virginia.

437 Their study started with pre-harvest measurements of water quality for six years on five 
438 watersheds. After the six year pre-harvest measurement period, four of the watersheds were

439 harvested with different treatments (commercial clearcut, diameter limit cut, extensive selection,

440 and intensive selection) and water quality was sampled again. The authors found that harvesting

441 timber can increase stormflow; careless logging causes high turbidity levels; poor skid trails

442 affect water quality; and the highest impact to water quality was immediately after the timber

443 harvest.

444 Martin and Pierce (1980) evaluated the effects of clearcutting on nitrate and calcium in streams

445 on the White Mountain National Forest in New Hampshire. Their study included: (1) water

446 quality sampling of nine streams from watersheds that were completely clearcut, (2) seven

447 streams from partially clearcut watersheds, and (3) seven streams from uncut watersheds. The

448 authors did not sample the watersheds pre-harvest. The authors found that leaving buffers around

449 streams and not clearcutting entire watersheds can reduce the magnitude and duration of nitrate

450 and calcium increases.

451 Patric (1980) studied the effects of harvesting on forest soils and water relations on the Fernow

452 Experimental Forest in West Virginia. His study was on a 34.7 ha watershed that evaluated

453 different harvesting treatments for the previous 20 years. The first treatment for this study

454 included clearcutting 31.7 ha of the watershed leaving a $20 \mathrm{~m}$ stream buffer strip on each side of

455 the stream. The second treatment harvested the buffer strip. The author found that sediment

456 concentrations in stormflow had small increases for the clearcut with a buffer strips but these

457 small increases had little effect on water quality. Patric (1980) did find when removing the buffer

458 strip, water yield and stream temperature increased, which were not affected when the buffer

459 strip was left. 
460 Martin and Hornbeck (1994) compared sediment yields and stream turbidity levels on harvested

461 and no harvest watersheds. Their study was on the Hubbard Brook Experimental Forest in New

462 Hampshire and consisted of three no harvest watersheds (reference) and four harvested

463 watersheds (clear-felled, strip-cut, mechanized whole-tree clearcut, and clearcut). The authors

464 evaluated sediment yield and turbidity on all the watersheds, however the clearcut watershed did

465 not include sediment yield measurements. Martin and Hornbeck (1994) found that sediment

466 yields increased from logging but did not find significant differences that affected water quality.

467 They concluded that BMPs will help control erosion and sedimentation.

468 Kochenderfer et al. (1997) evaluated the effectiveness of West Virginia BMPs on a 39 ha

469 watershed that was harvested to a $35.5 \mathrm{~cm}$ stump diameter limit. A John Deere 850 bulldozer

470 was used to create roads and skid trails and a wheeled skidder and tri-axle truck for primary and

471 secondary hauling. Harvesting resulted in significant increases in total stormflow and peakflows

472 during the growing season. However, the dormant season did not result in any significant

473 increases. They also found that suspended sediments doubled when the watershed was harvested

474 and that sediment exports returned to pre-treatment levels three years post-harvest. Kochenderfer

475 et al. (1997) concluded that West Virginia BMPs applied on the harvested watershed reduced

476 any critical impacts to water quality.

477 Bent (2001) assessed the effects of timber harvesting and herbicide applications on runoff and 478 ground water recharge in two drainage basins of central Massachusetts. Cadwell Creek and

479 Dickey Brook basins were examined and each included a treatment and control section. After

480 harvesting, the basal area was reduced by $34 \%$ and $32 \%$ in the Cadwell Creek basin and Dickey

481 Brook basin, respectively. The Cadwell Creek basin resulted in increased streamflow, direct

482 runoff, and ground water recharge for six years post-harvest, while the Dickey Brook basin only 
483 had increases for one year post-harvest. Bent (2001) suspected that the large stormflow increases

484 in Cadwell basin were caused by the location of harvest treatments and riparian zone.

$485 \quad 2.2 .4 \quad$ Non-Profit

486 Wilkerson et al. (2006) evaluated the effectiveness of stream buffers on headwater stream

487 temperature in western Maine. This study was conducted by Manomet. Five treatments on 15

488 streams included: (1) clearcutting with no buffer, (2) clearcutting with partially harvesting $11 \mathrm{~m}$

489 buffer, (3) clearcutting with partially harvesting $23 \mathrm{~m}$ buffer, (4) partial harvest with no defined

490 buffer, and (5) control. The authors found that after harvesting, the no buffer streams had the

491 highest increases in stream temperature. Additionally, both partially harvested $11 \mathrm{~m}$ and $23 \mathrm{~m}$

492 buffer treatments were sufficient in protecting stream temperature increases in headwater

493 streams.

494 VanBrakle et al. (2008) examined if forest management plans increase BMP implementation on

495 family forests in the New York City watershed. This study was conducted by the Watershed

496 Agricultural Council. The authors evaluated forestry BMPs for forest roads, skid trails, landings,

497 stream crossings (haul roads and skid trails), and water diversion. The only BMPs evaluated that

498 resulted in significantly higher implementation scores were skid trails and forest roads. The

499 authors suggested that possibly providing more programs to logger training and timber sale

500 contract education would help increase BMP implementation. 


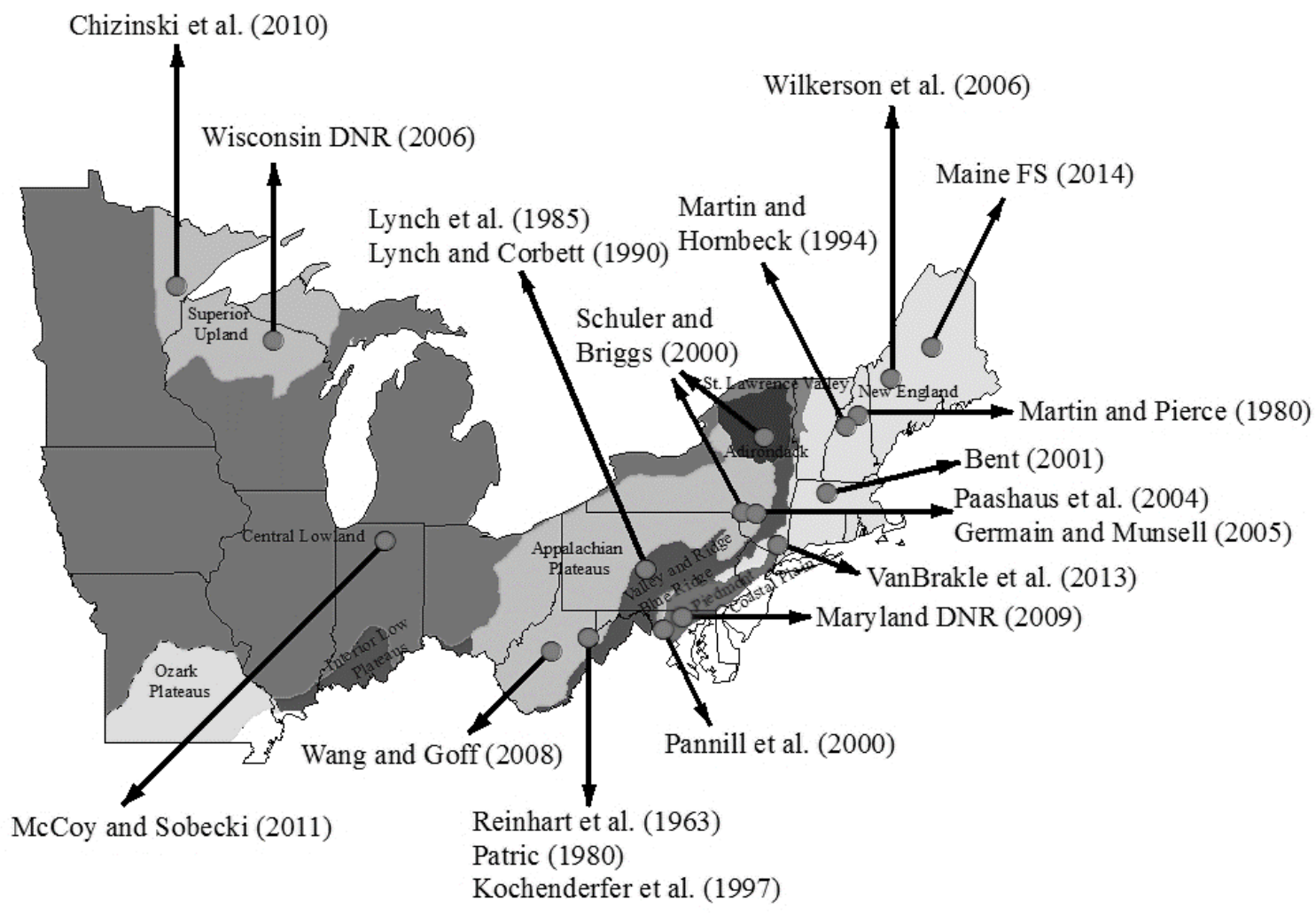

502 Figure 2. Reviewed BMP effectiveness studies by state and physiographic region for the northern United States. Locations were determined from the studies as well as Schilling 504 and Ice (2012). 

and treatments, and major conclusions.

\begin{tabular}{|c|c|c|c|c|}
\hline Investigators & $\begin{array}{l}\text { Region/ } \\
\text { Location }\end{array}$ & $\begin{array}{l}\text { Study } \\
\text { conducted } \\
\text { by }\end{array}$ & Evaluations/treatments & Major conclusions \\
\hline $\begin{array}{l}\text { Reinhart et } \\
\text { al. (1963) }\end{array}$ & West Virginia & Federal & $\begin{array}{l}\text { Effects of timber harvesting practices on } \\
\text { streamflow; treatments included: } \\
\text { commercial clearcutting, diameter limit } \\
\text { cutting, extensive selection management, } \\
\text { and intensive selection }\end{array}$ & $\begin{array}{l}\text { Timber harvesting increases storm } \\
\text { flow; water quality is affected due to } \\
\text { poor skid trails and logging; } \\
\text { unplanned skid trails caused water } \\
\text { quality issues }\end{array}$ \\
\hline $\begin{array}{l}\text { Martin and } \\
\text { Pierce (1980) }\end{array}$ & New Hampshire & Federal & $\begin{array}{l}\text { Effects of clearcutting on nitrate and } \\
\text { calcium in streams; treatments included: } 9 \\
\text { clearcut watersheds, } 7 \text { partially clearcut } \\
\text { watersheds, and } 7 \text { uncut watersheds }\end{array}$ & $\begin{array}{l}\text { Clearcutting less than entire } \\
\text { watersheds and leaving buffers around } \\
\text { streams reduced the magnitude and } \\
\text { duration of nitrate and calcium } \\
\text { increases }\end{array}$ \\
\hline Patric (1980) & $\begin{array}{l}\text { North central } \\
\text { West Virginia }\end{array}$ & Federal & $\begin{array}{l}\text { Effects of harvesting on forest soil and } \\
\text { water relations; two treatments: (1) } \\
\text { clearcut with } 20 \mathrm{~m} \text { buffer on both sides of } \\
\text { the stream and ( } 2 \text { ) harvesting } 20 \text { m buffer }\end{array}$ & $\begin{array}{l}\text { Treatment } 1 \text { resulted in no effect on } \\
\text { storm flow and stream temperature, } \\
\text { however water yield increased } 38 \% \\
\text { the first year after harvest, sediment } \\
\text { concentrations were low due to buffer } \\
\text { and management of logging roads; } \\
\text { treatment } 2 \text { increased water yield an } \\
\text { additional } 9 \% \text { and stream temperature } \\
7.8^{\circ} \mathrm{C}\end{array}$ \\
\hline
\end{tabular}




$\begin{array}{ll}\text { Lynch et al. } & \text { Central } \\ \text { (1985) } & \text { Pennsylvania }\end{array}$

$\begin{array}{ll}\text { Lynch and } & \text { Ridge and } \\ \text { Corbett } & \text { Valley (central } \\ \text { (1990) } & \text { Pennsylvania) }\end{array}$

$\begin{array}{lll}\text { Martin and } & \text { Central New } & \text { Federal } \\ \text { Hornbeck } & \text { Hampshire } & \\ \text { (1994) } & \end{array}$

Academia BMPs for controlling nonpoint source pollution; treatments included: (1) commercial clearcut, (2) clearcut with herbicide, and (3) control; BMPs were implemented on clearcuts; sampled water quality, turbidity, water temperature, and nutrient concentrations for two years after harvest

Academia Long-term (15-year) evaluation of BMPs for controlling nonpoint source pollution; paired watershed study included a control watershed (303 ac) and a $110 \mathrm{ac}$ commercial clearcut watershed (257 ac); evaluated changes in water quality and quantity

Compared sediment yields and stream turbidities on harvested and un-harvested watersheds; the study consisted of three control watersheds and four treatment watersheds; watershed treatments included: (1) clear-felled, (2) strip-cut (strips $25 \mathrm{~m}$ ), (3) mechanized whole tree clearcut, and (4) clearcut (no sediment data)
BMPs were effective in controlling nonpoint source pollution following logging in central Pennsylvania; slight increases in turbidity and sedimentation could have been from windblown trees near an intermittent stream channel and that buffer strips would have helped reduce erosion

Found small significant increase in nitrate and potassium concentrations and temperature and turbidity levels for first two years following the harvest; BMPs applied were effective because there were no serious changes in water quality; recommendations: conduct post-harvest inspections, increase buffer zone width, and include buffer zone on intermittent streams

Watersheds were harvested before state published BMPs; however logging did follow state BMPs for erosion control and sedimentation; sediment yields were not greatly affected from harvesting and skidding 


$\begin{array}{lll}\begin{array}{l}\text { Kochenderfer } \\ \text { et al. (1997) }\end{array} & \begin{array}{l}\text { Allegheny } \\ \text { Plateau }\end{array} & \text { Federal } \\ & \text { (West Virginia) } & \end{array}$

Pannill et al. Maryland

$\begin{array}{ll}\text { Schuler and } & \text { Catskill and } \\ \text { Briggs } & \text { Adirondack } \\ \text { (2000) } & \text { Regions } \\ & \text { (New York) }\end{array}$

Bent (2001) Central Massachusetts

State

Federal
Effectiveness of West Virginia BMPs on a 39 ha watershed that was harvested to a $35.5 \mathrm{~cm}$ stump diameter; John Deere 850 bulldozer used for roads and skid trails, wheeled skidders used for skidding, and tri-axle truck for hauling

Effectiveness of forestry BMPs in protecting water quality on a small watershed following forest harvesting; control watershed treatment and a timber harvested watershed that adhered to BMPs

Academia Application and effectiveness of 42

forestry BMPs on 61 harvested sites in Catskill Region and 53 harvested sites in the Adirondack Region; used evidence of sediment movement to define effectiveness

Effects of timber harvesting and herbicide application on runoff and ground water recharge for two separate paired drainage basins (Cadwell Creek and Dickey Brook)
Found that BMPs applied to the site were effective for reducing impacts to soil and water quality

BMPs implemented were effective in protecting stream water quality, biology, and habitat

Good application of BMPs decreased sediment movement which provided protection for surface waters; BMPs were effective; lower effectiveness of BMPs were due to imperfectly applied BMPs

Cadwell Creek basin resulted in increased streamflow, direct runoff, and ground water recharge for six years following the treatments and increased base flow for 2.5 years; Dickey Brook basin only had increased levels for one year following harvest; Dickey Brook was less influenced by the treatments because of location of riparian zones 
$\begin{array}{ll}\text { Paashaus et } & \text { Southern } \\ \text { al. (2004) } & \text { New York }\end{array}$

Germain and Catskills (New

Munsell York)

(2005)

Wilkerson et

al. (2006)

\section{Western Maine}

Academia

Impacts on macroinvertebrates in ephemeral streams from partial timber harvesting; bio-monitoring conducted on paired watersheds (control and treatment)

Academia

Assessed surface area disturbance by harvest access system; 43 nonindustrial private forest landowners northern hardwood harvested sites were evaluated

Non-profit

Effectiveness of different buffer widths for protecting headwater stream temperature following timber harvests; five treatments: (1) clearcut with no buffer, (2) clearcut with $11 \mathrm{~m}$ partially harvest buffer, (3) clearcut with $23 \mathrm{~m}$ partially harvested buffer, (4) partial cut with no defined buffer, and (5) control

Evaluated state forestry BMPs from 19952005
Macroinvertebrates in ephemeral streams were not impacted from partial timber harvesting

Found that high BMP implementation was positively related to the surface area (\%) disturbed; harvested sites with low disturbed area do not always equal high BMP implementation

Streams without buffers had the highest (significant) increase in weekly maximum temperatures; streams with the $11 \mathrm{~m}$ buffer showed minor increases but no significant increases; buffers consisting of at least an $11 \mathrm{~m}$ buffer were sufficient in protecting water temperature in small headwater streams

State BMP effectiveness is high when BMPs are applied correctly; when BMPs were not applied, impacts to water quality were found $71 \%$ of the time; found that BMPs were effective $99 \%$ of the time 


$\begin{array}{lll}\begin{array}{l}\text { Wang and } \\ \text { Goff (2008) }\end{array} & \text { West Virginia } \quad \text { State } & \text { Effectiveness of forestry BMPs; randomly } \\ & & \text { selected } 33 \text { of } 116 \text { sites from a previous } \\ & \text { state assessment that evaluated a timber } \\ & \text { harvest with an SMZ; Used the West } \\ & \text { Virginia BMP manual to evaluate haul } \\ & \text { roads, skid trails, landings, and SMZs }\end{array}$

Maryland Maryland $\quad$ State $\quad$ Forestry BMP implementation and

DNR (2009)

al. (2010) Minnesota

McCoy and Indiana

Sobecki

(2011) effectiveness for protecting water

resources in the state; evaluated 75 forest harvesting sites (2004-2005)

Academia Influence of partial timber harvests in riparian buffers on macroinvertebrate and fish communities in small streams; sampled benthic macroinvertebrate and fish one year prior to harvest and for three years following the harvest

State

Comprehensive review of Indiana BMP monitoring results from 1996-2011;

Indiana Division of Forestry monitored 671 sites in that time frame
Found that BMP application and effectiveness rates were higher on industrial land or with the involvement of a professional forester

BMPs were $77 \%$ effective in preventing sediment delivery; $4 \%$ of sites saw trace amounts of sediment; $19 \%$ of the sites had measureable amounts of sediment reaching water

Found few effects related to the harvest that affected macroinvertebrate communities and no significant changes in fish communities; timber harvesting to a certain degree in riparian buffers does not affect macroinvertebrate and fish communities in northern Minnesota

BMP effectiveness rate was 93\%; concluded that there has been little impact on water quality because of the high effectiveness rate (if BMPs are applied properly). 
VanBrakle et New York

al. (2013)

Maine FS Maine

(2014)
Non-profit

Examined if forest management plans increase BMP implementation on family forests in the New York City watershed; evaluated forest roads, landings, forest stream crossings, skid trails, skid trail stream crossings, and water diversion methods on private forestland

Assessed BMP effectiveness of Maine's BMPs; evaluated sites for sediment inputs into waterways
Minimal difference in BMP implementation between landowners that had management plans and landowners that did not have management plans; suggest that potentially moving funds from management plans to logger training and timber sale contract education programs

Found that $91 \%$ of the time there was no sediment entering waterways; BMPs are effective in preventing sedimentation when implemented properly 
512 BMP effectiveness studies in the Western US focus primarily on the Pacific Border

513 physiographic region where forest operations are most prevalent (Figure 3). Several effectiveness

514 studies used paired watershed experiments that included multiple studies, Alsea Watershed

515 (Oregon Coast Range), Caspar Creek Experimental Watershed (northwestern California), and

516 Mica Creek Experimental Watershed (northern Idaho). Thirty-one BMP effectiveness studies

517 from 1978 to 2015 were reviewed by the organization whom conducted the study: academia (9),

518 federal (12), state (5), industry (2), private (1), and non-profit (2) (Table 3).

$519 \quad 2.3 .1 \quad$ Academia

$520 \quad$ 2.3.1.1 Sediment Production

521 Beschta (1978) assessed the long-term patterns of sediment production from road construction

522 and logging on the Alsea Watershed in Oregon. This paired watershed study included three

523 treatment watersheds: (1) control (Flynn Creek), (2) clearcut, slash burning, and no stream

524 buffers (Needle Branch), and (3) patch-cut, roads, and burned (Deer Creek). The author found

525 that road construction and road failures in Deer Creek watershed significantly increased sediment

526 yield for three years post-treatment. The Needle Branch watershed resulted in 5 years of

527 increased sediment yields due to erosion from the slash burn and no stream buffer.

528 Karwan et al. (2007) evaluated suspended sediment loads from timber harvesting on the Mica

529 Creek Experimental Forest in northern Idaho. The authors used a paired watershed method and

530 monitored seven stream monitoring flumes for TSS from 1991-1997 (pre-harvest and pre-road

531 construction/improvement), 1998-2001 (post-road construction/improvement), and 2001-2004

532 (post-harvest). Treatments for forest roads included constructing new roads and improving

533 existing roads, while treatments for harvesting included: (1) 50\% commercial clearcut then 
534 broadcast, burned, and replanted, (2) 50\% partial harvest, and (3) control. Idaho's Forest Practice

535 Act (FPA) guidelines were followed. No significant differences in sediment loads among forest

536 road treatments in both harvested watersheds were detected. However, significantly higher

537 monthly sediment loads were reported within the commercially clearcut watershed after the

538 harvest, but significant differences dissipated after one year.

539 Beschta and Jackson (2008) summarized effects of road building, logging, and slash burning on

540 sediment production from past studies in the Alsea Watershed. Authors reported that

541 management practices such as minimizing road construction, clearcutting less area, applying

542 stream buffers, and low intensity slash burns can reduce sediment production. The authors

543 concluded that paired watershed studies similar to Alsea Watershed experiments are important

544 for demonstrating different forest practices and their effects on water quality.

$545 \quad$ 2.3.1.2 Stream Buffers

546 Jackson et al. (2001) assessed impacts of timber harvesting on 15 headwater streams in

547 Washington's Coast Range. The authors evaluated stream channel habitat, distributions of bed

548 material, and temperature. The treatments applied included: (1) no harvest (reference), (2)

549 clearcut with un-thinned buffer, (3) clearcut with partial buffer, and (4) clearcut with buffer

550 consisting of non-merchantable trees, and (5) clearcut with no buffer. The authors found

551 treatments with a stream buffer did not alter particle size distributions and habitat distributions

552 when compared to the no harvest treatments.

553 Jackson et al. (2007) built onto the study conducted by Jackson et al. (2001) by evaluating

554 abiotic and biotic responses to timber harvesting. The authors sampled geomorphology,

555 macroinvertebrates, and amphibians before and following timber harvesting. Jackson et al.

556 (2007) found that clearcutting with no buffers resulted in negative short-lived effects for some 
557 amphibian species. The authors also found that macroinvertebrate communities remained in flux

558 for both the buffered and no buffer streams and changes in communities were due to additional

559 organic matter from the harvest.

560 2.3.1.3 Water Yield and Water Quality

561 Stednick (2008a) assessed long-term streamflow changes after timber harvesting on the Alsea

562 Watershed. The author plotted differences in measured annual water yield and predicted

563 streamflows for the two treatment watersheds (Deer Creek and Needle Branch). The author

564 found that low flow metrics and peak flows were not significantly different than pre-treatment

565 levels and annual water yield increases in the Needle Branch watershed were not present after 31

566 years. The Deer Creek watershed had additional timber harvesting treatments and did not result

567 in any significant differences in flow metrics. Stednick (2008a) concluded that BMPs were

568 effective in not changing streamflow metrics.

569 Stednick (2008b) assessed the long-term water quality changes after timber harvesting on the

570 Alsea Watershed. The author found significantly lower nitrate-nitrogen concentrations after

571 timber harvesting in the Needle Branch (no buffer treatment) watershed when compared to the

572 control (Flynn Creek) and Deer Creek (patch-cut treatment) watersheds. However, there was a

573 significant increase in nitrate-nitrogen fluxes when compared to pre-treatment water quality

574 measurements. The Deer Creek watershed did not have any significant water quality changes

575 after multiple timber harvests. The author suggested this was caused by BMPs that were applied

576 on the watershed.

577 Gravelle et al. (2009) evaluated timber harvesting impacts on aquatic macroinvertebrates in the

578 Mica Creek Experimental Watershed in northern Idaho. Their study consisted of three

579 measurement periods over four years each: (1) calibration, (2) post roads, and (3) post-harvest. 
580 The authors sampled feeding groups, densities, taxa richness, diversity, and sediment tolerance

581 indices. Additionally, they assessed three main macroinvertebrate taxa (mayflies, stoneflies, and

582 caddis flies). Gravelle et al. (2009) did not find any changes in macroinvertebrate communities

583 from road construction and timber harvesting and suggested it was due to BMPs being followed.

$584 \quad 2.3 .2 \quad$ Federal

585 2.3.2.1 Sediment Production

586 Cook and King (1983) assessed the erosion control effectiveness of filter windrows on fill slopes

587 on the Nez Perce National Forest in Idaho. The authors evaluated filter windrows (sediment

588 barriers) of slash on newly constructed roads near stream crossings to determine their

589 effectiveness of reducing fill material from entering streams. The authors found that the filter

590 windrows trapped 75 to $95 \%$ of sediment and concluded that they are an inexpensive effective

591 method of preventing erosion from entering streams.

592 Ketcheson and Megahan (1996) evaluated sediment production and sediment transport

593 downslope caused by forest roads in granitic watersheds of southwestern Idaho. The authors

594 measured sediment deposits on constructed roads for four years. They found that $70 \%$ of the total

595 erosion occurred during the initial year following road construction. Ketcheson and Megahan

596 reported that erosion control treatments reduced erosion.

597 Cafferata and Spittler (1998) compared harvesting impacts in the Casper Creek watershed from

598 the 1970's to the 1990's. Two treatment watersheds (North Fork and South Fork) were

599 compared. South Fork roads were constructed in the 1960's and located near stream channels.

600 This watershed was selectively harvested using tractors in the 1970's. The North Fork was cable

601 logged (clearcut) between 1985 and 1991 and roads were located away from stream channels (on 602 ridges). The South Fork had higher sediment yield and erosion due to the harvest. The authors 
603 suspected that much of the sediment production was produced by legacy roads, which were 604 constructed prior to the FPA.

605 Lewis (1998) assessed erosion and suspended sediment transport from logging in the Casper

606 Creek watershed. The author measured suspended sediment, turbidity, and erosion and estimated 607 suspended sediment load and total sediment load on timber harvests conducted in the North Fork 608 (harvested with 1990 Forest Practice Rules) and South Fork (harvested before 1990 Forest 609 Practice Rules) watersheds. Lewis (1998) reported 1,475 kg ha $\mathrm{yr}^{-1}$ and 2,877 $\mathrm{kg} \mathrm{ha}^{-1} \mathrm{yr}^{-1} \mathrm{after}^{-1}$ 610 road construction and harvesting for the South Fork watershed. No effect was reported in the 611 North Fork watershed for sediment loads.

612 Madej et al (2012) assessed changes in land use practices on sediment loads in the Panther Creek 613 basin of the northwestern California. The author's evaluated timber harvesting methods and road 614 designs. Over half of the watershed was clearcut from harvests occurring between 1978 and 2008 615 with some thinning and selection harvesting also occurring. The authors stated that roads were 616 upgraded and some decommissioned between 2000 and 2009. Riparian buffers were left on 617 streams since 1984. Madej et al. (2012) found that the harvested area had a higher sediment yield 618 compared to the control (un-harvested). Most sediment issues were caused from landslides on 619 forest roads and landings. However, suspended sediment concentrations decreased due to 620 improved management practices.

621 O’Conner et al. (2007) assessed the effects of recent harvests and legacy management techniques 622 on sediment yield from first order streams in northwestern California. The study had three 623 treatments: (1) clearcut with a Habitat Conservation Plan (HCP), (2) clearcut without a HCP, and 624 (3) control. The authors used sediment basins to measure trapped sediment. O'Conner et al. 
625 (2007) did not find any significant differences between sites, but noted that HCP sites had lower

626 sedimentation when compared to sites without a HCP.

627 2.3.2.2 Water Yield and Water Quality

628 Keppeler and Ziemer (1990) assessed harvesting impacts on streamflow for 21 years on the

629 Casper Creek watershed in northwestern California. Their study included a control (North Fork;

630 prior to harvesting) and selective harvest with new road construction treatment (South Fork). The

631 authors measured water yield, volume, timing, and duration of low flows. Keppeler and Ziemer

632 (1990) found that the greatest increase in water yield was the first year after harvest. Water yield

633 decreased irregularly in the following years.

634 Dahlgren (1998) studied the effects of timber harvesting on stream water quality and nitrogen

635 cycling in the Casper Creek watershed. The author collected stream water quality samples from

636 both control and treatment (clearcut) watersheds and completed a nutrient cycling study. $\mathrm{He}$

637 found that nitrate concentrations were higher in clearcut and decreased downstream in higher

638 order streams. The author also reported a $1.8 \mathrm{~kg} \mathrm{~N} \mathrm{ha}^{-1} \mathrm{yr}^{-1}$ loss post-harvest and less than $0.4 \mathrm{~kg}$

$639 \mathrm{~N} \mathrm{ha}^{-1} \mathrm{yr}^{-1}$ three years post-harvest. The control watershed for the same period resulted in a

640 nitrogen loss less than $0.1 \mathrm{~kg} \mathrm{~N} \mathrm{ha}^{-1} \mathrm{yr}^{-1}$. Dahlgren noted that the nitrogen loss was small and

641 accredited the small loss to the redwood and Douglas-fir forest ecosystem.

642 Keppeler et al. (2008) evaluated the long-term patterns of hydrologic response post-harvesting in

643 in the Casper Creek watershed. The authors found that both the North Fork and South Fork had

644 similar water yield, peak flows, and low flows. Low flows returned to pre-harvest conditions

645 faster for selective logging. Keppeler et al. (2008) also found that sediment loads recovered

646 quickly after harvesting on both watersheds. However, 10-20 years post-harvest, sediment loads

647 increased due to road failures on the South Fork or pre-commercial thinning on the North Fork. 
648 Elliot (2010) evaluated the watershed processes from forest biomass harvesting in the western

649 United States. The author implemented BMPs to reduce impacts of biomass harvesting and

650 recommended two general guidelines: (1) minimize disturbances to the duff layer and soil and

651 (2) minimize and maintain roads. Elliot (2010) stated that increased road traffic and compacting

652 or disturbing the soil can increase erosion and runoff.

653 Klein et al. (2012) assessed turbidity levels from winter runoff on 28 coastal watersheds in

654 northern California. Study watersheds ranged from un-harvested redwood forests to commercial

655 harvesting. The authors found that the rate of timber harvesting and watershed drainage areas can

656 affect water quality. They stated that BMPs reduce erosion, but were not always implemented

657 properly. The authors also noted that in large watersheds harvested over a short period of time

658 can impact water quality.

659 USFS (2013) evaluated their Pacific Southwest Region BMP program from 2008 to 2010 to

660 determine BMP implementation and effectiveness. Similar evaluations were conducted in the

661 past by Staab (2004) and USFS (2009). BMP inspections were conducted on 2,237 randomly

662 selected sites. Reported BMP implementation was $91 \%$ with an effectiveness of $80 \%$.

663 Effectiveness was low due to water quality being affected at streams on roughly $12 \%$ of the sites.

664 The USFS (2013) found that BMPs for timber harvesting, fuels treatments, and vegetation

665 management was effective, however, BMPs for roads, range management, recreation, and

666 mining were not as effective. The USFS (2013) also noted that effectiveness can be increased by

667 improving erosion control plans and wet-weather standards.

$668 \quad 2.3 .3 \quad$ State

669 2.3.3.1 Water Quality 
670 Litschert and MacDonald (2009) assessed the frequency and characteristics of sediment delivery

671 pathways on harvested sites on National Forest land in the Sierra Nevada and Cascade mountains

672 of California. The authors evaluated 200 harvested sites that included SMZs and used the term

673 'features' to describe eroded areas of the harvest. They found 19 features on 200 sites that were

674 caused by rills or gullies (15) and sediment plumes (4). Sixteen of the features started from skid

675 trails of which five features connected to streams. The authors also found that feature length was

676 significantly related to hillslope gradient, mean annual precipitation, and elevation. Litschert and

677 MacDonald (2009) suggested that sediment delivery to streams can be reduced by: (1) locate

678 skid trails away from streams, (2) use waterbars with high surface roughness, and (3) close skid

679 trails.

680 Cafferata and Reid (2013) conducted a review of the long-term (50-year) watershed research

681 conducted at the Casper Creek watershed. The authors described the history and treatments

682 applied on both North and South Fork watersheds. They also provided key lessons learned and

683 findings from the past research. Some of the past research consisted of measuring peak flows,

684 water yield, hydrology, erosion, stream temperature, and sediment yields. Cafferata and Reid

685 (2013) noted that results and monitoring methods from the Casper Creek watershed were used to

686 address forestry issues in California and throughout the world. The authors also stated that

687 research is continuing on the watershed.

$688 \quad$ 2.3.3.2 Implementation and Effectiveness

689 Dubé et al. (2010) conducted a study assessing the Washington road sub-basin scale

690 effectiveness monitoring program. The objectives of this program were to determine if the new

691 Forest Fish Reports (FFRs) for forest roads improved protection of runoff and sediment delivery

692 and how many roads met FFR performance targets. The authors evaluated characteristics of 
693 forest roads over 60 sample units across the state of Washington (each unit was four square

694 miles). They found $62 \%$ of the units met FFR targets for hydrology performance. FFR targets for

695 sediment protection were met in $88 \%$ of the units.

696 Sugden et al. (2012) assessed Montana's forestry BMP program for the past 20 years. The

697 authors demonstrated the positive progression of Montana's BMP using past BMP audit reports.

698 In 1990, BMP implementation was $78 \%$ and increased to $97 \% 20$ years later. Water quality

699 infractions per harvest site decreased from eight in 1990 to less than 1 in 2010.

700 Brandow and Cafferata (2013) evaluated California’s Forest Practice Rules (FPR)

701 implementation and effectiveness monitoring program from 2008 to 2013. This study was based

702 off similar earlier studies conducted by Cafferata and Munn (2002) and Brandow et al. (2006).

703 The purpose of this study was to determine rate of implementation of FPRs and effectiveness of 704 FPRs in protecting water quality. The authors selected sites from California's Coastal, Cascade, 705 and Sierra Regions. Evaluations of sites indicated that implementation of FPRs were high and 706 FRPs were effective in preventing sedimentation. Brandow and Cafferata found that water 707 courses and lake protection zones, roads, and stream crossings had 90\% implementation or 708 higher depending on FPR. The authors suggested improvements to be made for stream crossing 709 design, construction and maintenance, and closure.

710 Ziesak (2015) reviewed 42 sites for BMP application and effectiveness for Montana's BMP

711 monitoring study in 2014. BMP application (implementation) was 97\% and BMP effectiveness

712 in protecting water quality was $98 \%$. Like previous monitoring reports from Montana, road

713 maintenance and road surface drainage were the main impacts on water quality.

$714 \quad 2.3 .4 \quad$ Industry 
715 Bilby et al. (1989) assessed road surface sediment production on five road segments in two

716 southwestern Washington watersheds. Two heavily trafficked roads located on valley-bottoms

717 were built in the 1950s. Three haul roads, built between 1968 and 1974, were located mid-slope.

718 Suspended sediments were analyzed on the sites. The authors found that sediment entered first

719 and second order streams $34 \%$ of the time and would temporary retain sediments from reaching

720 larger streams. Bilby et al. (1989) stated that steep roads that are heavily used and drain directly

721 into large streams will have a higher potential of impacting water quality.

722 Reiter et al. (2009) assessed temporal and spatial turbidity patterns over 30 years in the Pacific

723 Northwest of Washington. The authors used long-term data on stream discharge, suspended

724 sediment, turbidity, and water and air temperature to determine impacts of sediment control

725 practices on water quality. Data was collected at four permanent monitoring sites throughout the

726 study watershed. Turbidity declined at all four monitoring sites. The authors found that turbidity

727 levels when evaluated for the entire watershed declined, even during active forest operations.

728 Reiter et al. (2009) reported that declined sediment production was caused by increased attention

729 to forest practices for roads.

$\begin{array}{lll}730 & 2.3 .5 & \text { Private }\end{array}$

731 Rice (1999) evaluated erosion from logging roads on the Redwood Creek watershed in

732 northwestern California. The author stated that the roads were installed between 1950 and 1958

733 for logging and were maintained to standards of the past decade. His sample design consisted of

734100 sites within the $180 \mathrm{~km}$ of roads in the middle of the watershed. The author estimated the

735 mean erosion rate to be $177 \mathrm{~m}^{3} \mathrm{~km}^{-1}$ from 1980 to 1997 . The main source of erosion was from

736 the road cut banks. Rice (1999) noted that changes in FPRs (proper placement of culverts and

737 sizing of culverts) reduced erosion on logging roads. 


\subsubsection{Non-Profit}

739 Rice et al. (2004) conducted a review of the effects of forest management on erosion, sediment,

740 and runoff on the Caspar Creek watershed. The authors reported sediment loads were higher

741 before the 1973 FPA for selective logging and road construction. They also reported smaller but

742 significant increases in sediment from clearcutting following the 1990 FPA.

743 Rashin et al. (2006) assessed the effectiveness of BMPs on water quality impacts due to sediment

744 delivery in Washington. They evaluated BMPs for first two years post-harvest on 26 timber

745 harvested sites between 1992 and 1995. The authors used a weighted approach to determine

746 BMP effectiveness based on sediment delivery, disturbance of stream channels, and aquatic

747 habitat conditions. They found stream buffers were effective at preventing sediment delivery.

748 The authors also listed several factors that influenced BMP effectiveness: (1) equipment

749 disturbance near streams, (2) use of stream buffers, (3) use of proper harvesting practices to

750 minimize stream channel disturbance, and (4) time of year. 


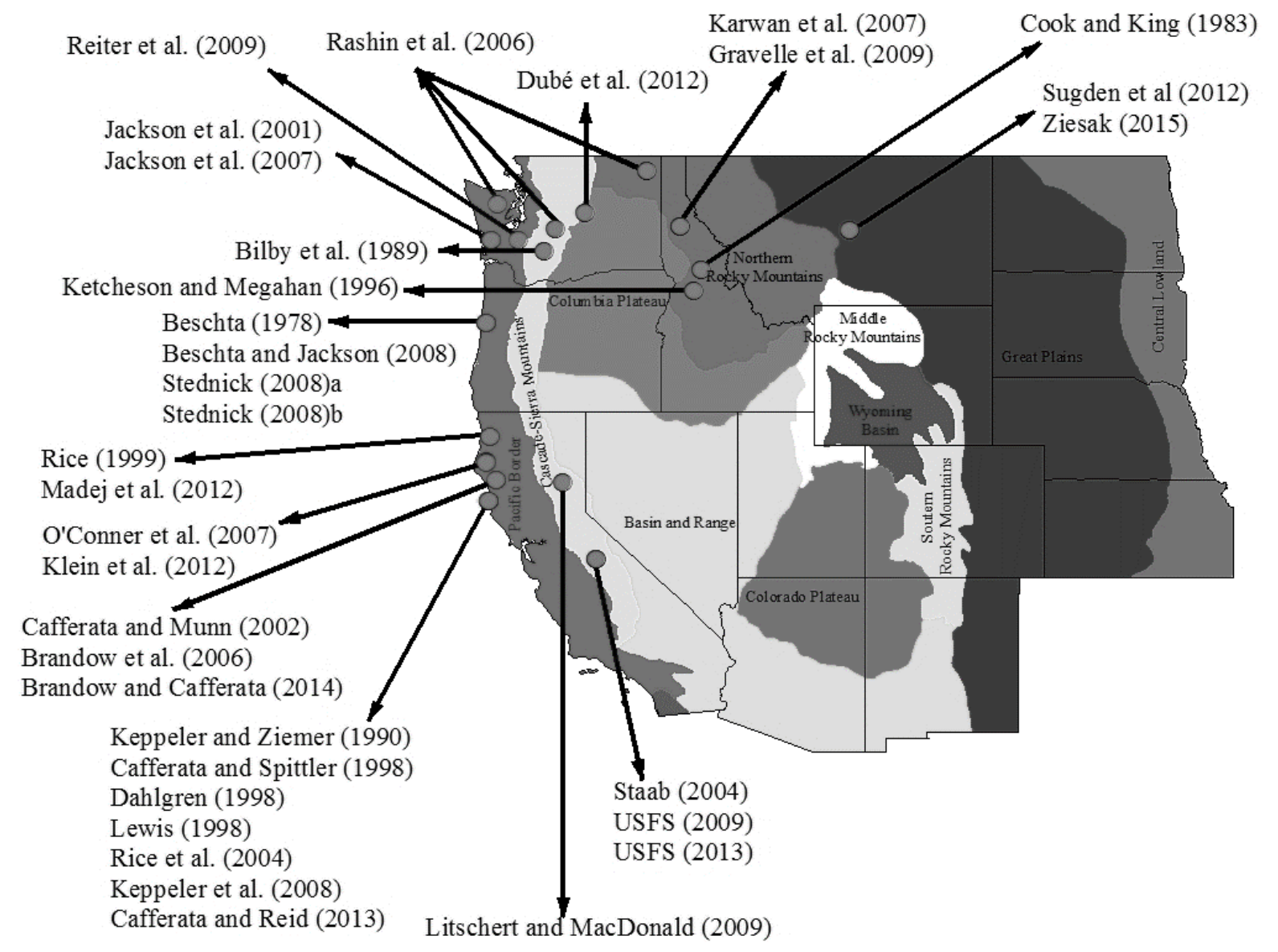

Figure 3. Reviewed BMP effectiveness studies by state and physiographic region for the Ice (2012). 

and treatments, and major conclusions.

\begin{tabular}{|c|c|c|c|c|}
\hline Investigators & $\begin{array}{l}\text { Region/ } \\
\text { Location }\end{array}$ & $\begin{array}{l}\text { Study } \\
\text { conducted } \\
\text { by }\end{array}$ & Evaluations/treatments & Major conclusions \\
\hline $\begin{array}{l}\text { Beschta } \\
\text { (1978) }\end{array}$ & $\begin{array}{l}\text { Coast Range } \\
\text { (Oregon) }\end{array}$ & Academia & $\begin{array}{l}\text { Long-term patterns of sediment production } \\
\text { following road construction and logging on } \\
\text { the Alsea Watershed; paired watershed study: } \\
\text { (1) control watershed (Flynn Creek), (2) } \\
\text { clearcut, slash burning, and no stream buffer } \\
\text { strips watershed (Needle Branch), and (3) } \\
\text { patch-cut, roads, and burned watershed (Deer } \\
\text { Creek) }\end{array}$ & $\begin{array}{l}\text { Deer Creek treatment resulted in } \\
\text { significant increases of sediment } \\
\text { yield for three years following } \\
\text { treatment due to road construction } \\
\text { and road associated failures; Needle } \\
\text { Creek treatment resulted in increased } \\
\text { sediment yield for five years } \\
\text { following treatment with the first } \\
\text { year resulting in a fivefold increase } \\
\text { primarily due to a severe slash fire } \\
\text { and logging along the stream channel }\end{array}$ \\
\hline $\begin{array}{l}\text { Cook and } \\
\text { King (1983) }\end{array}$ & Idaho & Federal & $\begin{array}{l}\text { Construction cost and erosion control } \\
\text { effectiveness of filter windrows on fill slopes; } \\
\text { monitored sediment barriers of slash on } \\
\text { newly constructed roads near stream } \\
\text { crossings }\end{array}$ & $\begin{array}{l}\text { Estimated sediment trapping } \\
\text { efficiency was between } 75 \% \text { and } \\
85 \% \text {; concluded that filter windrows } \\
\text { of slash were an inexpensive and } \\
\text { effective way to prevent erosion }\end{array}$ \\
\hline $\begin{array}{l}\text { Bilby et al. } \\
\text { (1989) }\end{array}$ & $\begin{array}{l}\text { Southwestern } \\
\text { Washington }\end{array}$ & Industry & $\begin{array}{l}\text { Fate of road-surface sediment in forested } \\
\text { watersheds; used new data and data from } \\
\text { previous road studies }\end{array}$ & $\begin{array}{l}\text { Roads with steep gradients, heavily } \\
\text { used, and drain directly into larger } \\
\text { streams have the greatest potential to } \\
\text { impact streams; problems with forest } \\
\text { roads can be reduced by applying } \\
\text { appropriate management procedures }\end{array}$ \\
\hline
\end{tabular}




$\begin{array}{lll}\text { Keppeler and } & \text { Northwestern } & \text { Federal } \\ \text { Ziemer } & \text { California } & \\ (1990) & \end{array}$

(1990)

$\begin{array}{lll}\text { Ketcheson } & \text { Southwestern } & \text { Federal } \\ \text { and Megahan } & \text { Idaho } & \end{array}$

(1996)

\section{Cafferata and Northwestern Federal Spittler California \\ (1998)}

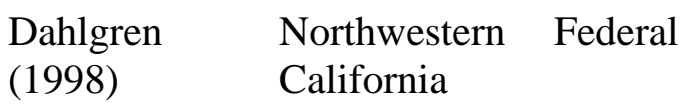

Logging effects on streamflow for a 21 year period on the Casper Creek Experimental

Watershed; evaluated selective tractor harvesting on volume, timing, and duration of low flows and annual water yield

Sediment production and downslope sediment transport from forest roads in granitic watersheds; measured annual downslope deposition of granitic sediments from forest roads; treatments included different erosion control practices

Compared logging impacts from the 1970s to the 1990s in the Casper Creek Experimental Watershed

Effects of forest harvesting on stream water quality and nitrogen cycling in the Casper Creek watershed; sampled water quality (clearcut vs. un-harvested); detailed nutrient cycling study
Greatest increase in water yield was during the initial year following the logging operation; water yields decreased irregularly the following years

Found that $70 \%$ of the sediment deposited on the slopes occurred during the first year after construction; standard erosion control practices for road construction resulted in an average annual erosion rate of $50.4 \mathrm{~m}^{3} \mathrm{ha}^{-1} \mathrm{yr}^{-1}$ and intensive erosion control practices for road construction resulted in an average erosion rate of $17.1 \mathrm{~m}^{3} \mathrm{ha}^{-1} \mathrm{yr}^{-1}$ (reduced erosion by 66\%)

Legacy roads that were constructed before the FPA continue to affect the South Fork watershed; concluded that legacy roads need to be properly closed under the new FPRs

Found higher concentrations of stream water nitrate in the clearcut watershed; nutrient losses in stream water in redwood-Douglas-fir forests after harvest were small compared to other forest types 
$\begin{array}{ll}\text { Lewis (1998) } & \begin{array}{l}\text { Northwestern Federal } \\ \text { California }\end{array}\end{array}$

Rice (1999) Northwestern Private California

Jackson et al. Coast Range

(2001) (Washington)

Rice et al. (2004)

Northwestern California

Non-profit

management effects on erosion, sediment, and runoff; Casper Creek Experimental Watershed

Evaluated the impacts of logging on erosion and suspended sediment transport in the Casper Creek watershed; South Fork harvested before 1990 FPRs; North Fork harvested after 1990 FPRs; measured and estimated suspended sediment concentrations.

Evaluated erosion from logging roads on the Redwood Creek watershed; measured erosion on 100 logging roads in the middle of the watershed.

Academia

Impacts of harvesting timber on 15 headwater streams; treatments included: (1) no harvest, (2) clearcut with un-thinned buffer, (3) clearcut with partial buffer, and (4) clearcut with buffer consisting of non-merchantable trees, and (5) clearcut with no buffer

Rashin et al. (2006)
Coast Range
(Washington)

Non-profit

Effectiveness of timber harvest practices for controlling sediment related water quality impacts; used a weight-of-evidence approach to determine BMP effectiveness and was based on sediment delivery to streams, disturbance to stream channels, and aquatic
Sediment load for the South Fork after road construction was $1475 \mathrm{~kg}$ $\mathrm{ha}^{-1} \mathrm{yr}^{-1}$ and $2877 \mathrm{~kg} \mathrm{ha}^{-1} \mathrm{yr}^{-1}$ after harvesting; no effect in the North Fork watershed for sediment loads

Found the estimated erosion rate to be $177 \mathrm{~m}^{3} \mathrm{~km}^{-}{ }^{1}$; noted that FPRs helped reduce erosion on logging roads

Found that particle size distribution and habitat distributions were not different when compared to the no harvest treatments.

Prior to the 1973 FPA, suspended sediment loads increased almost three-fold from road construction and selective logging; under the 1990 FPRs, there was a smaller, but significant increase in sediment from roads and clearcutting

Stream buffers were effective at limiting chronic sediment delivery and disturbance to stream channels; stream buffers of at least $10 \mathrm{~m}$ were most effective for timber felling and yarding activities; factors influencing 
habitat conditions

Jackson et al. Washington (2007)

Academia

Abiotic and biotic response to 15 headwater streams from timber harvesting; treatments were same as Jackson et al. (2001)

Academia Effects of timber harvesting on suspended sediment loads in the Mica Creek

Experimental Watershed; monitored seven automated stream monitoring flumes; pretreatment samples (1991-1997), post road construction samples (1998-2001), and post timber harvest samples (2001-2004); paired watershed approach (clearcut, partial harvest, reference)

O'Conner et Northwestern Federal al. (2007)

\section{Karwan et al. Norther
(2007)}

\section{California}

BMP effectiveness included: proximity of ground disturbance near waterways, use of stream buffers, use of proper timber falling and yarding practices, minimizing stream channel disturbance, and timing of timber harvest

No macroinvertebrate groups declined significantly over a three year period following the harvests; clearcutting with no SMZs had shortlived effects on some amphibian recovery

Road construction did not significantly affect sediment loads; harvesting timber did have a significant and immediate impact on sediment loads for the clearcut watershed; no significant differences in partial harvest; after one year there were no significant differences between the clearcut and control watersheds

Authors did not report any significant differences between sites that used a HCP and sites that did not; However, sites with a HCP tended to have lower sedimentation levels 
Beschta and

Jackson

(2008)

$\begin{array}{lll}\text { Keppeler et } & \text { Northwestern } & \text { Federal } \\ \text { al. (2008) } & \text { California } & \end{array}$

Keppeler
al. (2008)

Coast Range (Oregon)
Academia

Summarized sediment production from forest roads, logging, and slash burning on the Alsea Watershed

Long-term patterns of hydrologic response after logging in a coastal redwood forest; Casper Creek Experimental Watershed
Stednick

(2008a)

\section{Coast Range (Oregon)}

Academia

Long-term streamflow changes following timber harvesting on the Alsea Watershed study sites
Management practices such as minimizing road construction, small clearcuts, buffer strips, and low severity burns help reduce sediment problems

Post-treatments, sediment loads recovered quickly; however between 10-20 years after logging, sediment loads increased due to road failures on South Fork Watershed or due to pre-commercial thinning modifying hydrologic conditions on North Fork Watershed

Annual water yield increases were not detectable on the Needle Branch watershed after 31 years; peak flow and low flow metrics were not significant from pretreatment measurements; Deer Creek had timber harvests since the original treatments and there were no significant flow metrics from pretreatment measurements; application of BMPs resulted in no significant differences

Multiple timber harvests on Deer Creek did not have any significant 
study sites

$\begin{array}{ll}\text { Gravelle et } & \text { Northern } \\ \text { al. (2009) } & \text { Idaho }\end{array}$

Litschert and MacDonald (2009)

\section{Sierra Nevada and Cascade mountains} (California)
Academia Effects of timber harvesting on aquatic macroinvertebrate communities; sampling from 1994-2005 on Mica Creek Experimental Watershed; treatments: four year calibration period, four years of monitoring after forest roads were installed, and four years monitoring after timber harvest

Assessed the frequency and characteristics of sediment delivery pathways on harvested sites on National Forest land; evaluated 200 harvested sites that included SMZs; used 'features' to describe eroded areas of the harvest changes in water quality (BMPs followed); Needle Branch (no buffer strips) had a significant increase in nitrate-nitrogen fluxes immediately after the treatment, but showed a quick return to pretreatment conditions

Macroinvertebrate communities were not affected by road construction and timber harvesting; concluded that if BMPs are used appropriately, that similar areas to this study should have minimal effects on water quality and macroinvertebrate communities

Found 19 features on the 200 sites caused by rills or gullies (15) and sediment plumes (4); 16 of the features started from skid trails; five skid trail features connected to streams; feature length was significantly related to hillslope gradient, mean annual precipitation, and elevation; sediment delivery to streams can be reduced by: (1) locating skid trails away from streams, (2) using waterbars with high surface roughness, and (3) closing skid trails. 


$\begin{array}{llll}\begin{array}{l}\text { Reiter et al. } \\ \text { (2009) }\end{array} & \text { Cascade } & \text { Industry } & \text { Temporal and spatial turbidity patterns over } \\ & \text { Mountains } & & 30 \text { years in a managed forest; assessed } \\ & \text { (Washington) } & & \begin{array}{l}\text { sediment control methods and trends in } \\ \text { turbidity }\end{array}\end{array}$

$\begin{array}{lll}\begin{array}{l}\text { Dubé et al Washington } \quad \text { State } \\ \text { (2010) }\end{array} & \begin{array}{l}\text { Washington road sub-basin scale } \\ \text { effectiveness monitoring program; evaluated } \\ \end{array} \\ & \text { new FPRs for forest roads for improving } \\ & \text { protection of runoff and sediment delivery } \\ & \text { and determined how many roads meet the } \\ & \text { FFR performance targets; sampled } 60-4 \text { mile } \\ & \text { units }\end{array}$
$\begin{array}{lll}\text { Elliot (2010) } & \begin{array}{l}\text { Western } \\ \text { United States }\end{array} & \text { Federal } \\ & \end{array}$

Klein et al.

Northern

(2012)
Federal

California units

Effects of forest biomass used on watershed processes
Turbidity had a declining trend even with active forest management; concluded that this was due to improvements to road construction and maintenance practices for reducing road sedimentation and runoff

Found FFR targets for hydrology performance were met in $62 \%$ of the units and FFR targets for sediment protection were met in $88 \%$ of the units.

Two general guidelines to reduce or minimize impacts on the watershed from biomass harvesting: (1) minimize disturbance to duff layer and (2) minimize number of roads and maintain roads; concluded that increased traffic on forest roads and compacting and disturbing the soil can affect runoff and erosion and that BMPs should be used to reduce any risks

Rate of timber harvesting and watershed drainage areas can affect water quality; stated that hillslope hydrologic changes due to tree 


$\begin{array}{ll}\text { Madej et al. } & \begin{array}{l}\text { Northwestern } \\ \text { California }\end{array}\end{array}$

Sugden et al. Montana State (2012)

$\begin{array}{ll}\text { Cafferata and } & \text { Northwestern } \\ \text { Reid (2013) } & \text { California }\end{array}$

USFS (2013) Pacific Southwest Region (California)

Federal
Assessed changes in land use practices on sediment loads in the Panther Creek basin; treatment consisted of clearcut, thinning, and selective harvest and compared results to a control (un-harvested); evaluated sediment loads from timber harvesting methods and road designs

Assessed Montana's forestry BMP program for the past 20 years; used past BMP audits

50 years of watershed research in the Casper Creek watershed; review of the past watershed experiments on the North Fork and South Fork watersheds

Evaluated Pacific Southwest Region BMP program from 2008 to 2010; determine BMP implementation and effectiveness; 2237 randomly selected sites removal and root strength from decay should be included in the current BMPs and that erosion susceptible areas should limit rate of timber harvesting

Found that sediment yields were higher on treatment site, however suspended sediments concentrations have deceased compared to previous periods due to improved management practices

Forestry BMP implementation in 1990 was $78 \%$ and $97 \%$ in 2010;

Water quality infractions per harvest site have deceased to $<1$ over the 20 years

Author addressed key findings from past research; stated that research methods (monitoring technology and turbidity monitoring) conducted on the Casper Creek watershed have been used throughout the world; research is continuing on the watershed

BMP implementation was 91\%; BMP effectiveness was $80 \%$; BMPs for roads, range management, recreation, and mining were not as effective; 
noted effectiveness can be increased by improving erosion control plans and wet-weather standards.

\section{Brandow and California} Cafferata

Ziesak (2015) Montana
State

Evaluated California's FPRs implementation and effectiveness from 2008 to 2013; Coast, Cascade, and Sierra Regions
Implementation of FPRs were high and effective in preventing sedimentation; $90 \%$ or higher implementation for watercourses and lake protection zones, roads, and crossings; suggested improvements for stream crossing design,

construction and maintenance, and closure

42 sites evaluated for application and effectiveness; BMPs were applied $97 \%$ of the time; BMP were effective $98 \%$ of the time in protecting water quality; most frequent impacts on BMP effectiveness were associated with forest road maintenance and road surface drainage 


\section{Conclusion}

760 Results from this literature review indicate that forestry BMPs minimize water quality effects of

761 forest operations when implemented as recommended by state forestry agencies. While BMP

762 effectiveness studies are often site or region specific, they clearly demonstrate a common

763 outcome. Stuart and Edwards (2006) emphasized that BMPs based on physical principles

764 continue to be effective with the passage of time. These effectiveness studies provide critical

765 information and insight on how state BMP programs comply with the goals of the CWA.

766 Forestry BMP effectiveness studies can help states formulate or update BMP guidelines.

767 Effectiveness research commonly notes that areas such as forest roads, skid trails, and stream

768 crossings should receive considerable attention since they have the greatest potential for erosion

769 and sediment delivery. Research studies from multiple regions across the U.S. have

770 demonstrated that BMPs are effective and reduce sediment delivery to streams. Key conclusions

771 on BMP effectiveness for the research studies examined here were divided into two categories:

772 overall BMP effectiveness study conclusions and specific BMP guideline conclusions:

773 3.1 Overall BMP effectiveness study conclusions

774 - BMPs can minimize erosion and sedimentation.

775 - Implementation rates and quality are critical to BMP effectiveness for reduction of

$776 \quad$ erosion and sediment yield.

777 - BMP implementation can be enhanced with pre-operation planning and with the

778 involvement of a registered professional forester.

779 - Increased logger training and landowner knowledge of forestry BMPs can help improve 780 implementation. 
- Stream macroinvertebrates are typically not significantly affected by forest operations when BMPs are correctly applied.

3.2 Specific BMP guideline conclusions

- Forested SMZs are effective in trapping sediment and reducing stream TSS concentrations.

- Critically important BMP practices for forest roads include proper drainage structures, surfacing, erosion control of cut and fill slopes, traffic control, and closure.

- Sediment control structures applied to stream crossing approaches can significantly reduce runoff and sediment delivery.

- BMPs need to be applied during forest operations, not only as a closure measure.

- Effective skid trail closure practices can include installing waterbars and/or applying slash, mulch, or a combination of mulching and seeding.

- Improved stream crossings such as portable skidder bridges and temporary culverts can decrease TSS concentrations and turbidity compared to unimproved stream crossing structures.

\section{Literature Cited}

Adams, T.O., Hook, D.D., Floyd, M.A., 1995. Effectiveness monitoring of silvicultural best management practices in South Carolina. South. J. Appl. For. 19(4), 170-176.

Allen, H.L., Fox, T.R., Campbell, R.G., 2005. What is ahead for intensive pine plantation silviculture in the south? South. J. Appl. For. 29(2), 62-69.

Anderson, C.J., Lockaby, B.G., 2011. The effectiveness of forestry best management practices for sediment control in the southeastern United States: a literature review. South. J. Appl. For. 35(4), 170-177.

Appelboom, T., Chescheir, G., Skaggs, R., Hesterberg, D., 2002. Management practices for sediment reduction from forest roads in the coastal plains. Trans. ASABE. 45(2), 337344. 
Arthur, M., Coltharp, G., Brown, D., 1998. Effects of best management practices on forest streamwater quality in eastern Kentucky. J. Am. Water Resour. Assoc. 34(3), 481-495.

Aust, W.M., Blinn, C.R., 2004. Forestry best management practices for timber harvesting and site preparation in the eastern United States: an overview of water quality and productivity research during the past 20 years (1982-2002). Water, Air, Soil Pollut. 4(1), 5-36.

Aust, W.M., Carroll, M.B., Bolding, M.C., Dolloff, C.A., 2011. Operational forest stream crossings effects on water quality in the Virginia Piedmont. South. J. Appl. For. 35(3), 123-130.

Bent, G.C., 2001. Effects of forest-management activities on runoff components and groundwater recharge to Quabbin Reservoir, central Massachusetts. For. Ecol. Manage. 143, 115-129.

Beschta, R.L., 1978. Long-term patterns of sediment production following road construction and logging in the Oregon Coast Range. Water Resour. Res. 14(6), 1011-1016.

Beschta, R.L., Jackson, W.L., 2008. Forest practices and sediment production in the Alsea Watershed Study. Hydrological and Biological Responses to Forest Practices. Springer: 55-66.

Bilby, R.E., Sullivan, K., Duncan, S.H., 1989. The generation and fate of road-surface sediment in forested watersheds in southwestern Washington. For. Sci. 35(2), 453-468.

Blackburn, W.H., Wood, J.C, DeHaven, M.G., 1986. Storm flow and sediment losses from site-prepared forestland in East Texas. Water Resour.Res. 22(5), 776-784.

Brandow, C., Cafferata, P., Munn, J., 2006. Modified completion report monitoring program: monitoring results from 2001 through 2004. California State Board of Forestry and Fire Protection, Sacramento, CA: $80 \mathrm{p}$.

Brandow, C.A., Cafferata, P.H., 2014. Forest practice rules implementation and rffectiveness monitoring program (FORPRIEM): monitoring results from 2008 through 2013. California Department of Forestry and Fire Protection. Sacramento, CA: 169 p.

Brown, K.R., Aust, W.M., McGuire, K.J., 2013. Sediment delivery from bare and graveled forest road stream crossing approaches in the Virginia Piedmont. For. Ecol. Manage. 310, 836846.

Brown, K.R., McGuire, K.J., Aust, W.M., Hession, W.C., Dolloff, C.A., 2014. The effect of increasing gravel cover on forest roads for reduced sediment delivery to stream crossings. Hydro. Process. 29(6), 1129-1140.

Cafferata, P.H., Spittler, T.E., 1998. Logging impacts of the 1970's vs. the 1990's in the Caspar Creek watershed. Proceedings of the Conference on Coastal Watersheds: The Caspar Creek Story. USDA Forest Service, Pacific Southwest Research Station. PSW-GTR-168. 
Cafferata, P.H., Munn, J.R., 2002. Hillslope monitoring program: monitoring results from 1996 through 2001. California State Board of Forestry and Fire Protection. Sacramento, CA. $114 \mathrm{p}$.

Cafferata, P.H., Reid, L.M., 2013. Applications of long-term watershed research to forest management in California: 50 years of learning from the Caspar Creek experimental watersheds. California Department of Forestry and Fire Protection. California Forestry Report No. 5: 110 p.

Carroll, G., Schoenholtz, S., Young, B., Dibble, E., 2004. Effectiveness of forestry streamside management zones in the sand-clay hills of Mississippi: early indications. Water, Air, Soil Pollut. 4(1), 275-296.

Chizinski, C.J., Vondracek, B., Blinn, C.R., Newman, R.M., Atuke, D.M., Fredricks, K., Hemstad, N.A., Merten, E., Schlesser, N., 2010. The influence of partial timber harvesting in riparian buffers on macroinvertebrate and fish communities in small streams in Minnesota, USA. For. Ecol. Manage. 259(10), 1946-1958.

Clinton, B.D., 2011. Stream water responses to timber harvest: Riparian buffer width effectiveness. For. Ecol. Manage. 261(6), 979-988.

Cook, M.J., King, J.G., 1983. Construction cost and erosion control effectiveness of filter windrows on fill slopes. US Department of Agriculture, Forest Service, Intermountain Forest and Range Experiment Station.

Croke, J.C., Hairsine, P.B., 2006. Sediment delivery in managed forests: a review. Environ. Rev. 14(1), 59-87.

Dahlgren, R., 1998. Effects of forest harvest on stream-water quality and nitrogen cycling in the Caspar Creek Watershed. Proceedings of the conference on coastal watersheds: the Caspar Creek story. USDA Forest Service Gen. Tech. Rep. PSW-GTR-168: pp. 45-53.

Dubé, K., Shelly, A., Black, J., Kuzis, K., 2010. Washington road sub-basin scale effectiveness monitoring first sampling event (2006-2008) report. Departament of Natural Resources, State of Washington: $102 \mathrm{p}$.

DaSilva, A., Xu, Y.J., Ice, G., Beebe, J., Stich, R., 2013. Effects of timber harvesting with best management practices on ecosystem metabolism of a low gradient stream on the United States Gulf Coastal Plain. Water. 5(2), 747-766.

Edwards, P.J., Williard, K.W.J., 2010. Efficiencies of forestry best management practices for reducing sediment and nutrient losses in the eastern United States. J. For. 108(5), 245249.

Elliot, W.J., 2010. Effects of forest biomass use on watershed processes in the western United States. West. J. Appl. For. 25(1), 12-17. 
FDACS, 2014. Florida forestry wildlife best management practices for state imperiled species manual. Florida Department of Agriculture and Consumer Services: Florida Forest Service and Florida Fish and Wildlife Conservation Comission: 31p.

Fox, T.R., 2000. Sustained productivity in intensively managed forest plantations. For. Ecol. Manage. 138, 187-202.

Fritts, S.R., Moorman, C.E., Hazel, D.W., Jackson, B.D., 2014. Biomass harvesting guidelines affect downed woody debris retention. Biomass Bioenergy. 70, 382-391.

Grace, J.M., 2005. Forest operations and water quality in the south. Trans. ASABE. 48(2), 871880.

Grace, J.M., Elliot, W.J., 2011. Influence of forest roads and BMPs on soil erosion. Trans. ASABE Paper No. 1110633: 11p.

Gravelle, J.A., Link, T.E., Broglio, J.R., Braatne, J.H., 2009. Effects of timber harvest on aquatic macroinvertebrate community composition in a northern Idaho watershed. For. Sci. 55(4), 352-366.

Germain, R.H., Munsell, J.F., 2005. How much land is needed for the harvest access system on nonindustrial private forestlands dominated by northern hardwoods? North. J. Appl. For. 22(4), 243-247.

Grippo, R.S., McCord, S.B., 2006. Bioassessment of silviculture best management practices in Arkansas. Arkansas State University, College of Science and Mathematics: 206p.

Ice, G., 2004. History of innovative best management practice development and its role in addressing water quality limited waterbodies. J. Environ. Engineering. 130(6), 684-689.

Ice, G., Dent, L., Robben, J., Cafferata, P., Light, J., Sugden, B., Cundy, T., 2004. Programs assessing implementation and effectiveness of state forest practice rules and BMPs in the West. Water, Air, Soil Pollut. 4(1), 143-169.

Jackson, C.R., Sturm, C.A., Ward, J.M., 2001. Timber harvest impacts on small headwater stream channels in the Coast Ranges of Washington. J. Am. Water Resour. Assoc. 37(6), $18 \mathrm{p}$.

Jackson, C.R., Batzer, D.P., Cross, S.S., Haggerty, S.M., Sturm, C.A., 2007. Headwater streams and timber harvest: channel, macroinvertebrate, and amphibian response and recovery. For. Sci. 53(2), 356-370.

Karwan, D.L., Gravelle, J.A., Hubbart, J.A., 2007. Effects of timber harvest on suspended sediment loads in Mica Creek, Idaho. For. Sci. 53(2), 181-188.

Keim, R.F., Schoenholtz, S.H., 1999. Functions and effectiveness of silvicultural streamside management zones in loessial bluff forests. For. Ecol. Manage. 118, 197-209. 
Keppeler, E., Reid, L., Lisle, T., 2008. Long-term patterns of hydrologic response after logging in a coastal redwood forest. Proceedings of the Third Interagency Conference on Research in the Watersheds: 8-11.

Keppeler, E.T., Ziemer, R.R., 1990. Logging effects on streamflow: water yield and summer low flows at Caspar Creek in northwestern California. Water Resour. Res. 26(7), 1669-1679.

Ketcheson, G.L., Megahan, W.F., 1996. Sediment production and downslope sediment transport from forest roads in granitic watersheds. United States Department of Agriculture-Forest Service. Research Paper INT-RP-486.

Klein, R.D., Lewis, J., Buffleben, M.S., 2012. Logging and turbidity in the coastal watersheds of northern California. Geomorphology. 139-140, 136-144.

Kochenderfer, J.N., Edwards, P.J., Wood, F., 1997. Hydrologic impacts of logging an Appalachian watershed using West Virginia's best management practices. North. J. Appl. For. 14(4), 207-218.

Lakel, W.A., Aust, W.M., Bolding, M.C., Dolloff, C.A., Keyser, P., Feldt, R., 2010. Sediment trapping by streamside management zones of various widths after forest harvest and site preparation. For. Sci. 56(6), 541-551.

Lang, A., Aust, W.M., Bolding, M.C., Barrett, S.M., McGuire, K.J., Lakel, W.A., 2015. Streamside Management Zones Compromised by Stream Crossings, Legacy Gullies, and Over-Harvest in the Piedmont. J. Am. Water Resour. Assoc. 51(4), 1153-1164.

Lewis, J., 1998. Evaluating the impacts of logging activities on erosion and suspended sediment transport in the Caspar Creek watersheds. Proceedings of the conference on coastal watersheds: the Caspar Creek story. USDA Forest Service Gen. Tech. Rep. PSW-GTR168.

Litschert, S.E., MacDonald, L.H., 2009. Frequency and characteristics of sediment delivery pathways from forest harvest units to streams. For. Ecol. Manage. 259(2), 143-150.

Loehle, C., Wigley Jr, T.B., Lucier Jr, A., Schilling, E., Danehy, R.J., Ice, G., 2014. Toward improved water quality in forestry: opportunities and challenges in a changing regulatory environment. J. For. 112(1), 41-47.

Lynch, J.A., Corbett, E.S., 1990. Evaluation of best management practices for controlling nonpoint pollution from silviculture operations. J. Am. Water Resour. Assoc. 26(1), 4152.

Lynch, J.A., Corbett, E.S., Mussallem, K., 1985. Best management practices for controlling nonpoint-source pollution on forested watersheds. J. Soil Water Conserv. 40(1), 164-167.

Madej, M.A., Bundros, G., Klein, R., 2012. Assessing effects of changing land use practices on sediment loads in Panther Creek, North Coastal California. Proceedings of coast redwood 
forests in a changing California: a symposium for scientists and managers. USDA Forest Service Gen. Tech. Rep. PSW-GTR-238: pp. 101-109.

Maine FS 2014. Maine forestry best management practices (BMP) use and effectiveness—data summary 2013. Department of Agriculture, Conservation and Forestry: Maine Forest Service.

Martin, C.W., Hornbeck, J.W., 1994. Logging in New England need not cause sedimentation of streams. North. J. Appl. For. 11(1), 17-23.

Martin, C.W., Pierce, R.S., 1980. Clearcutting patterns affect nitrate and calcium in streams of New Hampshire. J. For. 78(5), 268-272.

Maryland DNR, 2009. Forestry best management practices in Maryland: implementation and effectiveness for protection of water resources. Maryland Department of Natural Resources Forest Service: 48p.

Mc Clurkin, D., Duffy, P., Ursic, S., Nelson, N., 1985. Water quality effects of clearcutting upper coastal plain loblolly pine plantations. J. Environ. Quality. 14(3), 329-332.

McBroom, M.W., Beasley, R.S., Chang, M., Ice, G.G., 2008. Storm runoff and sediment losses from forest clearcutting and stand re-establishment with best management practices in East Texas, USA. Hydro. Process. 22(10), 1509-1522.

McCoy, D., Sobecki, J., 2011. Comprehensive Indiana forestry best management practices monitoring results 1996-2011. Indiana Department of Natural Resources Division of Forestry: 56p.

Morris, B.C., Aust, W.M., Bolding, M.C., 2015. Effectiveness of forestry BMPS for stream crossing sediment reduction using rainfall simulation. Procceedings 17th Biennial Southern Silvicultural Research Conference. Shreveport, Louisiana.

NCASI, 1994. Southern regional review of state nonpoint source control programs and best management practices for forest management operations. New York, NY. National Council of the Paper Industry for Air and Stream Improvement, Inc. Technical Bulletin No. 686 .

NCASI, 1996. North Central states nonpoint source pollution control program review. Research Triangle Park, NC. National Council for Air and Stream Improvement, Inc. Technical Bulletin No. 710.

NCASI, 2012. Assessing the effectiveness of contemporary forestry best management practices (BMPs): focus on roads. Research Triangle Park, NC. National Council for Air and Stream Improvement, Inc. Special Report No. 12-01.

O'connor, M., Perry, C., McDavitt, W., 2007. Sediment yield from first-order streams in managed redwood forests: effects of recent harvests and legacy management practices. USDA Forest Service Gen. Tech. Rep. PSW-GTR-194: 431-443. 
Paashaus, E., Briggs, R., Ringler, N., 2004. Partial cutting impacts on macroinvertebrates in ephemeral streams in southern NY. Proccedings Forestry Across Borders: New England Society of American Foresters 84th Winter Meeting. Northeastern Research Station.

Patric, J.H., 1980. Effects of wood products harvest on forest soil and water relations. J. Environ. Quality. 9(1), 73-80.

1001

1002

1003

1004

1005

1006

1007

1008

1009

1010

1011

1012

1013

1014

1015

1016

1017

1018

1019

1020

1021

1022

1023

1024 1025

1026

1027

1028

Pannill, P., McCoy, J., O’Ney, S., Bare, C., Primrose, N., Bowen, S., 2000. Evaluating the effectiveness of Maryland's best management practices for forest harvesting operations. Maryland Department of Natural Resources, Annapolis, Maryland: 32p.

Phillips, M.J., Blinn, C.R., 2004. Best management practices compliance monitoring approaches for forestry in the eastern United States. Water, Air, Soil Pollut. 4(1), 263-274.

Rashin, E.B., Clishe, C.J., Loch, A.T., Bell, J.M., 2006. Effectiveness of timber harvest practices for controlling sediment related water quality impacts. J. Am. Water Resour. Assoc. 42(5), 1307-1327.

Reinhart, K.G., Eschner, A.R., Trimble Jr, G., 1963. Effect on streamflow of four forest practices in the mountains of West Virginia. U.S. Department of Agriculture-Forest Service, Northeastern Forest Experiment Station: 79p.

Reiter, M., Heffner, J.T., Beech, S., Turner, T., Bilby, R.E., 2009. Temporal and spatial turbidity patterns over 30 years in a managed forest of western Washington. J. Am. Water Resour. Assoc. 45(3), 793-808.

Rice, R.M., 1999. Erosion on logging roads in Redwood Creek, northwestern California. J. Am. Water Resour. Assoc. 35(5), 1171-1182.

Rice, R.M., Ziemer, R.R., Lewis, J., 2004. Evaluating forest management effects on erosion, sediment, and runoff: Caspar Creek and northwestern California. A Century of Forest and Wildland Watershed Lessons. Bethesda, MD. Society of American Foresters: 223-238.

Rivenbark, B.L., Jackson, C.R., 2004. Concentrated flow breakthroughs moving through silvicultural streamside management zones: southeastern Piedmont, USA. J. Am. Water Resour. Assoc. 40(4), 1043-1052.

Ruhlman, M.B., 1999. Effectiveness of forestry best management practices: evaluating water quality from intensely managed watersheds. Proceedings Georgia Water Resources Conference: $126-129$.

Rummer, B., 2004. Managing water quality in wetlands with forestry BMP's. Water, Air, Soil Pollut. 4(1), 55-66.

Sawyers, B., Bolding, M., Aust, W., Lakel, W., 2012. Effectiveness and implementation costs of overland skid trail closure techniques in the Virginia Piedmont. J. Soil Water Conserv. 67(4), 300-310. 
1029

1030

1031

1032

1033

1034

1035

1036

1037

1038

1039

1040

1041

1042

1043

1044

1045

1046

1047

1048

1049

1050

1051

1052

1053

1054

1055

1056

1057

1058

1059

1060

1061

1062

1063

1064

1065

Schilling, E., Ice, G., 2012. Assessing the effectiveness of contemporary forestry best management practices (BMPs): focus on roads. NCASI. Special Report No. 12-01: 68p.

Schuler, J.L., Briggs, R.D., 2000. Assessing application and effectiveness of forestry best management practices in New York. North. J. Appl. For. 17(4), 125-134.

Shepard, J.P., 2006. Water quality protection in bioenergy production: the US system of forestry best management practices. Biomass Bioenergy. 30(4), 378-384.

Simpson, H., Work, D., Harrington, S., 2008. Evaluating the effectiveness of Texas forestry best management practices: results from the Texas silvicultural BMP effectiveness monitoring project 2003-2007. Texas Forest Service, Lufkin, Texas: 39p.

Staab, B., 2004. Best management practices evaluation program, 2008-2010. Final Report. USDA Forest Sevice, Pacific Southwest Region. Vallejo, CA: 76 p.

Stednick, J.D., 2008a. Long-term streamflow changes following timber harvesting. Hydrological and Biological Responses to Forest Practices. Springer: 139-155.

Stednick, J.D., 2008b. Long-term water quality changes following timber harvesting. Hydrological and Biological Responses to Forest Practices. Springer: 157-170.

Stuart, G.W., Edwards, P.J., 2006. Concepts about forests and water. North. J. Appl. For. 23(1), 11-19.

Sugden, B.D., Ethridge, R., Mathieus, G., Heffernan, P.E., Frank, G., Sanders, G., 2012. Montana's forestry best management practices program: 20 years of continuous improvement. J. For. 110(6), 328-336.

Turton, D.J., Smolen, M.D., Stebler, E., 2009. Effectiveness of BMPS in reducing sediment from unpaved roads in the Stillwater Creek, Oklahoma watershed. J. Am. Water Resour. Assoc. 45(6), 1343-1351.

US EPA, 2005. National management measures to control nonpoint source pollution from forestry. United State Environmental Protection Agency: 276p.

USFS, 2009. Water quality protection on national forests in the Pacific Southwest Region: best management practices evaluation program, 2003-2007. USDA Forest Sevice, Pacific Southwest Region. Vallejo, CA: 28 p.

USFS, 2013. Water quality protection on national forests in the Pacific Southwest Region: best management practices evaluation program, 2008-2010. USDA Forest Sevice, Pacific Southwest Region. Vallejo, CA: 42 p.

VanBrakle, J.D., Germain, R.H., Munsell, J.F., Stehman, S.V., 2013. Do forest management plans increase best management practices implementation on family forests? A formative evaluation in the New York City watershed. J. For. 111(2), 108-114. 
1066

1067

1068

1069

1070

1071

1072

1073

1074

1075

1076

1077

1078

1079

1080

1081

1082

1083

1084

1085

1086

1087

1088

1089

1090

1091

1092

1093

1094

1095

1096

1097

1098

1099

Vowell, J.L., 2001. Using stream bioassessment to monitor best management practice effectiveness. For. Ecol. Manage. 143, 237-244.

Vowell, J.L., Frydenborg, R.B., 2004. A biological assessment of best management practice effectiveness during intensive silviculture and forest chemical application. Water, Air, Soil Pollut. 4, 297-307.

Wade, C.R., Bolding, M.C., Aust, W.M., Lakel, W.A., 2012. Comparison of five erosion control techniques for bladed skid trails in Virginia. South. J. Appl. For. 36(4), 191-197.

Walling, D., 1983. The sediment delivery problem. J. Hydro. 65(1), 209-237.

Wang, J., Goff, W.A., 2008. Application and effectiveness of forestry best management practices in West Virginia. North. J. Appl. For. 25(1), 32-37.

Ward, J.M., Jackson, C.R., 2004. Sediment trapping within forestry streamside management zones: Georgia Piedmont, USA. J. Am. Water Resour. Assoc. 40(6), 1421-1431.

Wear, L.R., Aust, W.M., Bolding, M.C., Strahm, B.D., Dolloff, C.A., 2013. Effectiveness of best management practices for sediment reduction at operational forest stream crossings. For. Ecol. Manage. 289, 551-561.

Wilkerson, E., Hagan, J.M., Siegel, D., Whitman, A.A., 2006. The effectiveness of different buffer widths for protecting headwater stream temperature in Maine. For. Sci. 52(3), 221231.

Williams, T.M., Hook, D.D., Lipscomb, D.J., Zeng, X., Albiston, J.W., 1999. Effectiveness of best management practices to protect water quality in the South Carolina Piedmont. Proceedings Tenth Biennial Southern Silvicultural Research Conference.

Wisconsin DNR, 2006. Wisconsin's forestry best management practices for water quality 1995 2005. Wisconsin Department of Natural Resources: Forest Service: $24 p$.

Witt, E.L., Barton, C.D., Stringer, J.W., Bowker, D.W., Kolka, R.K., 2013. Evaluating best management practices for ephemeral stream protection following forest harvest in the Cumberland Plateau. South. J. Appl. For. 37(1), 36-44.

Wynn, T., Mostaghimi, S., Frazee, J., McClellan, P., Shaffer, R., Aust, W., 2000. Effects of forest harvesting best management practices on surface water quality in the Virginia Coastal Plain. Trans. ASABE. 43(4), 927-936.

Yoho, N.S., 1980. Forest management and sediment production in the South--a review. South. J. Appl. For. 4(1), 27-36.

Ziesak, R., 2015. Montana forestry best management practice monitoring: 2014 forestry BMP field review report results. Montana Department of Natural Resources and Conservation, Missoula Montana: 66p. 